\title{
A portable, robust, stable, and tunable calibration source for gas-phase nitrous acid (HONO)
}

\author{
Melodie Lao ${ }^{1}$, Leigh R. Crilley ${ }^{1}$, Leyla Salehpoor ${ }^{1}$, Teles C. Furlani ${ }^{1}$, Ilann Bourgeois ${ }^{2,3}$, J. Andrew Neuman ${ }^{2,3}$, \\ Andrew W. Rollins ${ }^{2}$, Patrick R. Veres ${ }^{2}$, Rebecca A. Washenfelder ${ }^{2}$, Caroline C. Womack ${ }^{2,3}$, Cora J. Young ${ }^{1}$, and \\ Trevor C. VandenBoer ${ }^{1}$ \\ ${ }^{1}$ Department of Chemistry, York University, Toronto, ON, Canada \\ ${ }^{2}$ NOAA Chemical Sciences Laboratory, Boulder, CO, USA \\ ${ }^{3}$ Cooperative Institute for Research in Environmental Sciences, University of Colorado, Boulder, CO, USA
}

Correspondence: Trevor C. VandenBoer (tvandenb@yorku.ca)

Received: 28 May 2020 - Discussion started: 16 June 2020

Revised: 16 August 2020 - Accepted: 11 September 2020 - Published: 6 November 2020

\begin{abstract}
Atmospheric HONO mixing ratios in indoor and outdoor environments span a range of less than a few parts per trillion by volume (pptv) up to tens of parts per billion by volume (ppbv) in combustion plumes. Previous HONO calibration sources have utilized proton transfer acid displacement from nitrite salts or solutions, with output that ranges from tens to thousands of ppbv. Instrument calibrations have thus required large dilution flows to obtain atmospherically relevant mixing ratios. Here we present a simple universal source to reach very low HONO calibration mixing ratios using a nitrite-coated reaction device with the addition of humid air and/or $\mathrm{HCl}$ from a permeation device. The calibration source developed in this work can generate HONO across the atmospherically relevant range and has high purity ( $>90 \%$ ), reproducibility, and tunability. Mixing ratios at the tens of pptv level are easily reached with reasonable dilution flows. The calibration source can be assembled to start producing stable HONO mixing ratios (relative standard error, RSE $\leq 2 \%$ ) within $2 \mathrm{~h}$, with output concentrations varying $\leq 25 \%$ following simulated transport or complete disassembly of the instrument and with $\leq 10 \%$ under ideal conditions. The simplicity of this source makes it highly versatile for field and lab experiments. The platform facilitates a new level of accuracy in established instrumentation, as well as intercomparison studies to identify systematic HONO measurement bias and interferences.
\end{abstract}

\section{Introduction}

In the lower troposphere, the hydroxyl radical $(\mathrm{OH})$ is the principal daytime gas-phase oxidant and will react with volatile organic compounds (VOCs) to form secondary pollutants such as ozone $\left(\mathrm{O}_{3}\right)$ and secondary organic aerosols (Spataro and Ianniello, 2014; Ye et al., 2018). Photolysis of nitrous acid (HONO) is a direct source of the hydroxyl radical $(\mathrm{OH})$ (Reaction R1). Consequently, this can be a significant contributor to the integrated daily $\mathrm{OH}$ budget, ranging from $4 \%$ to $56 \%$ in urban areas (Lee et al., 2013; Volkamer et al., 2010) up to $80 \%$ in semirural areas in the winter (Kim et al., 2014), along with additional vertical and temporal variability (Crilley et al., 2016; Young et al., 2012; Zhang et al., 2009).

$\mathrm{HONO}_{(\mathrm{g})}+h v(\lambda<405 \mathrm{~nm}) \rightarrow \mathrm{OH}_{(\mathrm{g})}+\mathrm{NO}_{(\mathrm{g})}$

The reported daytime mixing ratios of ambient HONO outdoors can vary considerably for different environments, ranging from a few parts per trillion by volume (pptv) in the clean remote marine and Arctic boundary layers (Honrath et al., 2002; Kasibhatla et al., 2018; Reed et al., 2017) to 18 parts per billion by volume (ppbv) in polluted megacities such as Milan, Los Angeles, and Beijing (Elshorbany et al., 2009; Febo et al., 1996; Harris et al., 1982; Tong et al., 2016; Zhang et al., 2019). Measurements within biomass burning plumes from forest fires have shown very high HONO levels, often up to $60 \mathrm{ppbv}$ (Chai et al., 2019; Neuman et al., 2016; Veres et al., 2010b). There is a growing body of evidence that HONO concentrations can be significant in indoor 
environments, with levels up to $50 \mathrm{ppbv}$ reported from gas stove cooking emissions (Collins et al., 2018; Gligorovski, 2016; Gómez Alvarez et al., 2012; Liu et al., 2019; Young et al., 2019; Zhou et al., 2018). There are a number of atmospheric HONO sources that have been reported: direct emissions (e.g., vehicles and biomass burning), gas-phase homogenous reaction of $\mathrm{NO}$ and $\mathrm{OH}$, biological production in soils (Mushinski et al., 2019), and a number of heterogeneous surface reactions (Spataro and Ianniello, 2014, and references therein). Despite the importance of HONO to atmospheric photochemistry and radical budgets, the contribution of these sources to observed HONO levels is still poorly constrained, particularly during the daytime (Gall et al., 2016; Kleffmann, 2007; Lee et al., 2016; Oswald et al., 2013; Pusede et al., 2015; Sörgel et al., 2015; Tsai et al., 2018; Ye et al., 2016).

Due to the importance of HONO in our understanding of tropospheric photochemical oxidation and indoor atmospheric oxidation chemistry, accurate and precise quantitative measurements are required. However, gas-phase HONO has remained a challenging compound to measure due to several instrument artifacts and interferences. Within inlet lines, positive artifacts can occur as a result of heterogenous HONO formation on wet surfaces (Kleffmann and Wiesen, 2008; Zhou et al., 2002), while the reactive nature of HONO can also lead to negative artifacts due to wall losses (Pinto et al., 2014). Furthermore, there can be interferences from ambient components in the atmospheric matrix, such as the reduction of $\mathrm{NO}_{2}$ by numerous compounds, as well as particulate nitrite (Kleffmann et al., 2006; Kleffmann and Wiesen, 2008; Rubio et al., 2009; Sörgel et al., 2011; VandenBoer et al., 2014). Recent intercomparison studies have shown substantial differences between various HONO measurement techniques (Cheng et al., 2013; Crilley et al., 2019; Pinto et al., 2014; Stutz et al., 2010). Crilley et al. (2019) observed that while different HONO measurement techniques agreed on the temporal trends in HONO concentrations, the reported absolute concentrations displayed systematic variation. Most studies are unable to pinpoint the exact cause of the observed divergence between instruments; it may be due to spatial heterogeneity in ambient HONO concentration, unknown chemical interference(s), and/or differences in the accuracy and precision of calibration approaches. A portable calibration unit compatible with all instruments/techniques could assist in ruling out systematic bias and identifying interferences between instruments during intercomparison studies.

A variety of approaches have been used in the past to generate gaseous HONO standards. Most of these depend on acid displacement from a solution containing nitrite $\left(\mathrm{NO}_{2}^{-}\right)$ or from solid sodium nitrite $\left(\mathrm{NaNO}_{2}\right)$. Acids used have included sulfuric acid, hydrochloric acid, and oxalic acid, with evaporation of $\mathrm{NH}_{4} \mathrm{NO}_{2}$ also reported (Braman and de la Cantera, 1986; Febo et al., 1995; Taira and Kanda, 1990; Večeřa and Dasgupta, 1991). By far the most widely employed modern HONO calibration methods stem from the report of Febo et al. (1995), who presented a system for generating a continuous source of stable gas-phase HONO in the tens of ppbv to parts per million by volume (ppmv) range. This system utilized the reaction between gas-phase hydrochloric acid $(\mathrm{HCl})$ and $\mathrm{NaNO}_{2}$ powder to generate gasphase HONO, as described in Reaction (R2):

$\mathrm{NaNO}_{2(\mathrm{~s})}+\mathrm{HCl}_{(\mathrm{g})} \rightarrow \mathrm{HONO}_{(\mathrm{g})}+\mathrm{NaCl}_{(\mathrm{s})}$

However, this calibration source requires a gas-tight vessel of $\mathrm{HCl}$ solution contained in a thermostatic bath that presents considerable difficulty for many field measurement applications. Adaptations include immersing thin-wall Teflon tubing in concentrated $\mathrm{HCl}$, high-concentration $\mathrm{HCl}$ cylinders, and $\mathrm{HCl}$ permeation devices. Gaseous $\mathrm{HCl}$ generated by these methods then mixes with loose $\mathrm{NaNO}_{2}$ crystals in a stirred reactor (Stutz et al., 2000), dispersed using $3 \mathrm{~mm}$ glass beads packed in PFA tubing to increase porosity (Roberts et al., 2010), or pieces of PFA tubing (McGrath et al., 2019; VandenBoer et al., 2015; Zhou et al., 2018). These adapted approaches have been used to calibrate many atmospheric HONO instruments (Crilley et al., 2019; Heland et al., 2001; Ren et al., 2010; Roberts et al., 2010; Stutz et al., 2000; VandenBoer et al., 2013, 2015; Wang and Zhang, 2000; Young et al., 2012). An alternative approach that utilised dilute $\mathrm{H}_{2} \mathrm{SO}_{4}$ for the acid displacement reaction with aqueous $\mathrm{NaNO}_{2}$ was outlined by Taira and Kanda (1990). While this approach was shown to generate a stable and tunable HONO output at hundreds of ppbv, it has not been widely adapted, likely due to the need for complex custom glassware and liquid flow control in the calibration apparatus and significant dilution to reach single-digit ppbv mixing ratios (Kleffmann et al., 2004).

While widely used, the method described by Febo et al. (1995) presents several practical challenges. The typically high HONO mixing ratios generated by this approach (up to $20 \mathrm{ppmv}$ ) are challenging to dilute to atmospherically relevant mixing ratios. The high quantities also lead to autodissociation of HONO (Reaction R3), resulting in the production of nitrogen oxide impurities of $\mathrm{NO}$ and $\mathrm{NO}_{2}$ (Febo et al., 1995; Neuman et al., 2016), and CINO in the presence of $\mathrm{HCl}$ at ppmv levels (Gingerysty and Osthoff, 2020).

$$
\mathrm{HONO}_{(\mathrm{g})}+\mathrm{HONO}_{(\mathrm{ads})} \rightarrow \mathrm{NO}_{(\mathrm{g})}+\mathrm{NO}_{2(\mathrm{~g})}+\mathrm{H}_{2} \mathrm{O}
$$

Further, to reduce the variability in HONO output over time, the powdered $\mathrm{NaNO}_{2}$ bed requires continuous mixing to maintain equilibrium between the adsorbed HONO and carrier gas flowing over the salt bed to minimize the production of $\mathrm{NO}_{x}$ by Reaction (R3), as well as a Teflon filter to prevent loss of $\mathrm{NaNO}_{2}$ powder by entrainment in the gas flow. The degradation of the powdered $\mathrm{NaNO}_{2}$ structure can limit the lifetime of the source and results in unstable HONO production rates (Febo et al., 1995; Gingerysty and Osthoff, 2020). Other systems using dispersed $\mathrm{NaNO}_{2}$ suffer from sensitivity to vibration, causing changes in HONO output and limiting 
calibration accuracy (Zhou et al., 2018). Once operational, the original or modified methods require up to a day to stabilize, and these systems must be kept continuously operating and stationary to preserve the HONO output stability.

One solution for producing gaseous $\mathrm{HCl}$ for acid displacement is to use a temperature-controlled permeation device (PD). A permeation oven is a simple instrument that can be used for the preparation of low mixing ratios of gases from ppbv to ppmv levels (Veres et al., 2010a; Washenfelder et al., 2003). This approach has been used to generate a consistent quantity of gaseous analytes for over 400 compounds because it is low cost, portable, and robust (Mitchell, 2000). Permeation devices are typically made of inert polymer tube of known permeability filled with a (semi)volatile liquid. Both ends of the device are sealed either with caps or permeable plugs, and the emission is determined by the surface area and thickness of permeable polymer, the concentration of the contained solution, and the temperature (O'Keeffe and Ortman, 1966; Susaya et al., 2012).

The aim of the current work was to make a portable and easy to assemble HONO calibration instrument compatible with HONO-measuring instruments commonly used within the atmospheric research community. We developed coated devices to facilitate reactions of sodium nitrite $\left(\mathrm{NaNO}_{2}\right)$ which release HONO when exposed to water vapor and $\mathrm{HCl}$ (Reaction R2). Herein we demonstrate that the $\mathrm{NaNO}_{2}$ coated reaction devices produce a stable and continuous supply of high-purity gaseous HONO. The output of this HONO calibration source spans the range of environmentally relevant mixing ratios, up to tens of ppbv. The emission quantities, mass balance, and purity of gaseous HONO were determined through a series of control tests with various instruments. We present evidence of its robustness, reproducibility, and stability in HONO output. Finally, we evaluated methods to control the mixing ratio output of the calibration source and provide several approaches and recommendations on its use.

\section{Experimental methods}

\subsection{Coated $\mathrm{NaNO}_{2}$ reaction devices}

Reactions of $\mathrm{NaNO}_{2}$ on humidified surfaces produce HONO. A large and consistent surface area is required to reproducibly produce $\mathrm{HONO}$ at the desired levels.

A NaNO $_{2}$ (EMSURE ${ }^{\circledR}$; ACS Reag. Ph Eur, Germany) coating solution was made as a $20 \mathrm{gL}^{-1} \mathrm{NaNO}_{2}$ solution. The coating solution solvent was composed of equal volumes of methanol (HPLC grade; Fisher Chemicals, Ottawa, $\mathrm{ON})$ and $18.2 \mathrm{M} \Omega \mathrm{cm}$ deionized water with $1.0 \mathrm{~g} \mathrm{~L}^{-1}$ glycerol (Sigma Chemical Company, St. Louis, MO, USA) to facilitate a uniform salt coating. The solution was made by dissolving the $\mathrm{NaNO}_{2}$ in the water first, followed by the addition of the glycerol and then methanol. The coating solu- tion was stored in an HDPE bottle wrapped in aluminum foil at $4{ }^{\circ} \mathrm{C}$ until needed and remade every 3 months. To coat a reaction device, $3 \mathrm{~mL}$ of coating solution was first transferred into a heat-straightened $1 / 2 \mathrm{in}$. $(1.27 \mathrm{~cm})$ PFA tube with a length of $14.4 \mathrm{~cm}$ and surface area of $86.2 \mathrm{~cm}^{2}$. Rubber stoppers with centered $4.5 \mathrm{~mm}$ holes were inserted into both ends of the PFA tube to reduce solution loss while evaporating the solvent. The PFA reaction device was repeatedly inverted and rotated while covering both stopper holes to coat the inner surface completely. The reaction device was then dried by insertion into an $8 \mathrm{in} .(20 \mathrm{~cm})$ length of aluminum pipe $(1-1 / 4$ in. $/ 3.18 \mathrm{~cm}$ i.d.) and placed onto heated stainless steel rollers to evenly coat the PFA reaction device surface as the solution evaporates over a few hours (Nostalgia Electrics, RHD800 Retro Series; or Great Northern Popcorn Company, 4078 GNP Hotdog 7 Roller Machine). Until their experimental use, prepared $\mathrm{NaNO}_{2}$ PFA reaction devices were sealed with Parafilm or vinyl end caps (McMaster-Carr; part no. $40005 \mathrm{~K} 14)$ and kept in a dark box at room temperature.

Teflon-coated aluminum annular denuders (URG-200030x150-3CSS, URG Corporation, Chapel Hill, NC) were also used in some experiments in place of the $\mathrm{NaNO}_{2}$ device (Fig. 1). To coat these denuders, $3.0 \mathrm{~mL}$ of the $\mathrm{NaNO}_{2}$ coating solution was transferred to the device, followed by capping, inversion, rotation, and shaking to ensure all concentric etched glass surfaces were coated. The excess $\mathrm{NaNO}_{2}$ coating was decanted and the denuder dried with zero air at a flow of 1.0 standard liter per minute (SLPM) for about $10 \mathrm{~min}$ at room temperature.

\subsection{Gas flows}

The calibration source, which uses a permeation oven and $\mathrm{NaNO}_{2}$ reaction device to generate HONO, was designed to be cost-effective, lightweight, and robust for use with dry compressed air as the carrier gas (Fig. 1). Full technical details of the design rationale and assembly of the custom-built permeation oven can be found in the Supplement (Sects. S1S2, Figs. S1-S5), with only a brief description given below. $\mathrm{A} \mathrm{NO}_{x}$ analyzer was used to characterize the output from the HONO source. A single cylinder or zero air generator provided the separate carrier gas flows required for the $\mathrm{PD}$, a humidifier, and a dilution flow.

Carrier gas flow through the permeation oven was provided by a compressed cylinder of zero air or nitrogen (Praxair; Air Ultra Zero, 99.999\%, AI 0.0UZ-K; high-purity nitrogen, $99.998 \%$, NI 4.8, Toronto, ON), but an in situ zero air generator could also be used (e.g., Aadco Instruments model 747-10, Cleves, $\mathrm{OH}$; used only for dilution flows here), providing $20 \mathrm{psi}$ of pressure to control the flow entering a four-way $1 / 4 \mathrm{in}$. $(64 \mathrm{~mm})$ Swagelok cross fitting. The zero air flows through two critical orifices setting flows of $\sim 50 \mathrm{sccm}$ (sccm: standard cubic centimeters per minute; Lenox Laser, Glen Arm, MD; SS-4-VCR-2-50) and a mass flow controller (MFC; MKS Instruments, Inc.; 


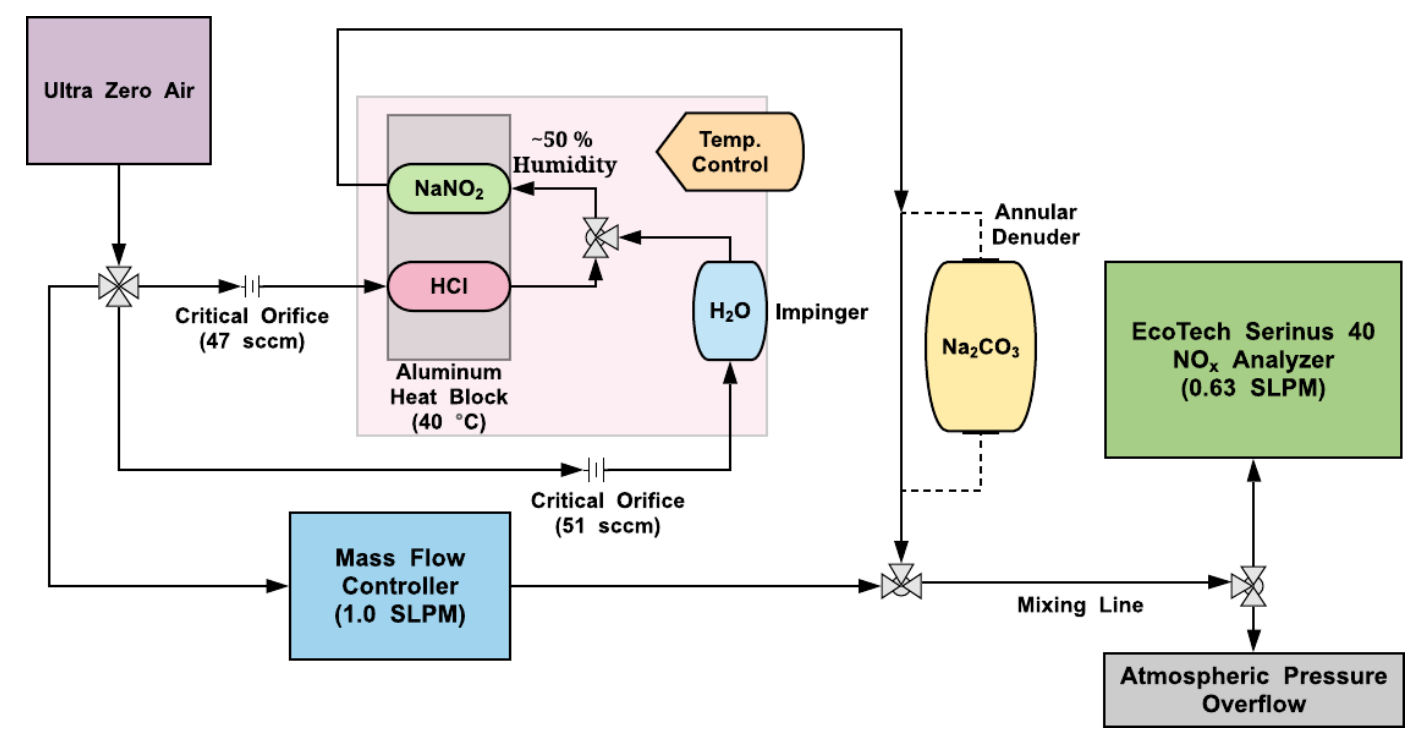

Figure 1. Flow and component schematic of the HONO calibration system (pink shaded region) interfaced with a $\mathrm{NO}_{x}$ analyzer $($ green), dilution mass flow controller (blue), and an exchangeable $\mathrm{Na}_{2} \mathrm{CO}_{3}$ annular denuder (yellow). Lines with black arrows denote the direction of gas flow through system components. Tee and cross fittings are denoted by arrays of grey triangles.

M100B00814CS1BV, 10 SLPM, gas; AIR, Kanata, Canada) set to deliver a dilution flow of 1.0 SLPM. A proportionalintegral-differential (PID) temperature controller (Omega ${ }^{\mathrm{TM}}$; CN 7823, Saint-Eustache, QC, Canada) was used to regulate the temperature of a machined aluminum $(\mathrm{Al})$ block. The first critical orifice connects to the $\mathrm{HCl}$ PD channel within the heated Al block, and the second connects to a $25 \mathrm{~mL}$ glass impinger (EMD Millipore Corporation, Billerica, MA, USA) containing deionized water at room temperature. The flows are combined and mixed to a resultant relative humidity $(\mathrm{RH})$ of $50 \%$, which then enters the coated $\mathrm{NaNO}_{2}$ reaction device in the temperature-controlled $\mathrm{Al}$ block. The $\mathrm{HCl}$ drives the acid displacement reaction in the $\mathrm{NaNO}_{2}$-coated PFA device, releasing HONO into the gas phase. The flow exits the oven into the dilution flow being delivered to an instrument or experimental system. If operating in cold environments, care should be taken to ensure the $50 \% \mathrm{RH}$ exiting the calibration system does not generate condensation in the lines.

\subsection{Custom-built HCl permeation devices (PDs)}

Although PDs are available from commercial suppliers, they are custom-made here to reduce costs, as described in detail in the Supplement (Sect. S2, Fig. S5). Briefly, custom PDs are made from PFA tubing $(3.2 \mathrm{~mm}$ i.d. with $5 \mathrm{~mm}$ o.d., part no. 5733K73; McMaster-Carr, Aurora, OH) fitted with PTFE plugs (3.2 mm diameter, part no. 84935K64; McMaster-Carr). A series of $\mathrm{HCl}$ PDs were made as aqueous solutions to obtain PDs containing 1.2 and $6 \mathrm{M} \mathrm{HCl}$ solutions (OmniTrace ${ }^{\circledR} ; 34 \%-37 \%$, HX0607-1, Sigma-Aldrich, Oakville, ON; Table 1). During operation the $\mathrm{HCl} \mathrm{PD}$ is placed within the $1 / 2 \mathrm{in}$. tubing in the heating block, through which the carrier gas is flushed.

\subsection{NO $\mathrm{N}_{x}$ analyzer for HONO detection}

The output from the HONO calibration source was monitored using a commercial chemiluminescent $\mathrm{NO}_{x}$ analyzer fitted with a Mo catalytic converter, set to $325^{\circ} \mathrm{C}$ (Serinus 40, American Ecotech, Warren, RI). The conversion efficiency of $\mathrm{NO}_{2}$ to $\mathrm{NO}$ was calculated by combining known concentrations of NO from a standard cylinder (Praxair; NI NO5MC-A3, $4.88( \pm 5 \%)$ ppmv, Toronto, $\mathrm{ON})$ and $\mathrm{O}_{3}$ using a gas calibration instrument (Gascal 1100TS, American Ecotech, Warren, RI). The conversion efficiency was determined according to the manufacturer specifications at 98.84 $( \pm 0.38 \%)$ for $\mathrm{NO}_{2}$ mixing ratios delivered to the system spanning 100 to 400 ppbv. While the Mo catalyst is meant to convert $\mathrm{NO}_{2}$ to $\mathrm{NO}$ for detection by the analyzer, it is well known that HONO is also quantitatively converted to NO (Febo et al., 1995), and the conversion efficiency was determined experimentally (Sect. 2.6). A $\mathrm{NO}_{x}$ analyzer was preferred to other independent calibration methods such as ion chromatography with conductivity detection (IC-CD), as it is capable of continuous real-time measurement of HONO, allowing rapid frequent checks on the calibration source output stability.

During experiments, $\sim 100 \mathrm{sccm}$ from the HONO source was diluted into an additional 1.0 SLPM of zero air from which the $\mathrm{NO}_{x}$ instrument sampled 0.63 SLPM (Fig. 1). The $\mathrm{NO}_{x}$ analyzer measured $\mathrm{NO}$ on either the $\mathrm{NO}$ or $\mathrm{NO}_{x}$ channels for an averaging period of $1 \mathrm{~min}$ with the Kalman filter set to 60 or $300 \mathrm{~s}$. To correct for instrument drift or $\mathrm{NO}_{x}$ 
Table 1. Description of custom-made $\mathrm{HCl}$ permeation devices used to generate $\mathrm{HONO}$. Zero-air-corrected mixing ratios of emitted $\mathrm{HCl}$ and generated $\mathrm{HONO}$ using a single $\mathrm{NaNO}_{2}$-coated PFA reaction device were measured with the heated $\mathrm{Al}$ block at $40^{\circ} \mathrm{C}$ in 1.1 . SLPM. The variability reported for each observation represents 1 standard deviation from the mean $(n=30$ to 60 using 1 min averaged data).

\begin{tabular}{lrrrrrrr}
\hline PD & $\begin{array}{r}\mathrm{HCl} \\
(\mathrm{M})\end{array}$ & $\begin{array}{r}\text { Date of Manufacture } \\
(\mathrm{YYYY} / \mathrm{MM})\end{array}$ & $\begin{array}{r}\text { PFA Device } \\
(\mathrm{cm})\end{array}$ & $\begin{array}{r}\text { PTFE Plug } \\
(\mathrm{cm})\end{array}$ & $\begin{array}{r}\mathrm{HCl} \\
(\mathrm{ppbv})\end{array}$ & $\begin{array}{r}\text { HONO } \\
(\mathrm{ppbv})\end{array}$ & $\begin{array}{r}\text { Measured Date } \\
(\mathrm{YYYY} / \mathrm{MM})\end{array}$ \\
\hline PD-1 & 1.2 & $2017 / 04$ & 9.92 & 0.60 & $0.58 \pm 0.01$ & $0.95 \pm 0.51$ & $2019 / 10$ \\
PD-6a & 6 & $2017 / 04$ & 9.41 & 0.70 & $0.21 \pm 0.01$ & $0.88 \pm 0.4$ & $2019 / 10$ \\
PD-6b & 6 & $2019 / 04$ & 9.11 & 0.75 & $2.0 \pm 0.01$ & $2.8 \pm 0.41$ & $2019 / 11$ \\
PD-6c & 6 & $2019 / 04$ & 9.65 & 0.70 & $5.0 \pm 0.3$ & $6.2 \pm 0.5$ & $2019 / 11$ \\
\hline
\end{tabular}

contamination in the zero air, the analyzer was flushed for at least $15 \mathrm{~min}$ at the beginning and end of each experiment. An annular denuder coated with $20 \mathrm{~g} \mathrm{~L}^{-1}$ sodium carbonate in $50: 50$ methanol and water solution $\left(\mathrm{Na}_{2} \mathrm{CO}_{3}\right.$; ACS reagent $>$ 99.7\%; Sigma-Aldrich, St. Louis, MO) - similar to that used here for $\mathrm{NaNO}_{2}$ - was inserted during some experiments to scrub HONO from the experimental flow (Fig. 1). The denuder was prepared by transferring $10 \mathrm{~mL}$ of $\mathrm{Na}_{2} \mathrm{CO}_{3}-$ coating solution, capping, and then inverting and rotating to distribute the solution evenly. The remainder of the coating solution was decanted and the denuder surfaces dried under a flow of 1.0 SLPM of zero air until completely dry ( $\sim 10 \mathrm{~min})$. The denuder was inserted into experimental flows for at least $1 \mathrm{~h}$ as a second check on sources of background $\mathrm{NO}$ and $\mathrm{NO}_{2}$ as impurities being emitted from the calibration source or carrier gas. $\mathrm{A} \mathrm{Na}_{2} \mathrm{CO}_{3}$ denuder can also be used as a robust alternative to provide the $\mathrm{NO}_{x}$ analyzer inlet overflow instead of a cylinder of zero air. This enables corrections of HONO measurements or calibrations for $\mathrm{NO}_{x}$ present in the sample air or calibration source carrier gas, respectively.

\subsection{Conversion efficiency of the $\mathrm{NO}_{x}$ analyzer Mo catalyst for HONO}

A Mo catalyst at $325^{\circ} \mathrm{C}$ will reduce $\mathrm{HONO}$ to $\mathrm{NO}$, though reports have shown that this conversion may vary between $\mathrm{NO}_{x}$ analyzers (McGrath et al., 2019; Zhou et al., 2018). We measured the HONO generated by the calibration source with the $\mathrm{NO}_{x}$ analyzer and then directed the HONO to a scrubbing solution of $1 \mathrm{mM} \mathrm{NaOH}$ in two glass impingers connected in series for several hours to days to collect $\mathrm{NO}_{2}^{-}$ to a level that could be quantified by IC-CD. The second bubbler was used to determine the extent that HONO was quantitatively collected in the first bubbler (i.e., to capture any breakthrough). The HONO generated by the calibration source and quantified by IC was compared to the $\mathrm{NO}_{x}$ analyzer measurement, using the introduction of a $\mathrm{Na}_{2} \mathrm{CO}_{3}$ annular denuder to perform background correction. The HONO conversion efficiency determined by comparison to the IC was found to be $104 \pm 4 \%(n=3)$, confirming unit conversion efficiency, with the associated error set by the $4 \%$ accuracy of the IC-CD method for $\mathrm{NO}_{2}^{-}\left(R^{2}>0.999\right)$ when employing our previously developed separation method (Place et al., 2018). The IC precision near the analyzed concentrations for $\mathrm{NO}_{2}^{-}$was measured to be $3 \%$. All data presented in this paper therefore use a conversion efficiency of unity for the Mo catalyst.

\subsection{Supporting instrumentation}

In our mass balance experiments for the production mechanisms governing HONO generation in the calibration system, we used two additional tools to monitor experimental gas flows. Mixing ratios of $\mathrm{HCl}$ were measured at $0.5 \mathrm{~Hz}$ using a cavity ring-down spectrometer (CRDS) (G2108 HCl gas concentration analyzer, Picarro, Santa Clara, CA) with a $5 \mathrm{pptv}$ detection limit for $1 \mathrm{~min}$ averaged data. Further details on the performance of this instrumentation can be found in Dawe et al. (2019). Measurements of $\mathrm{HCl}$ and $\mathrm{HONO}$ to investigate acid displacement efficiency of the calibration system were performed at $2 \mathrm{~Hz}$ using a quadrupole chemical ionization mass spectrometer (CIMS, THS Instruments LLC, Atlanta, GA) using acetate reagent ions to facilitate proton transfer and detection of negative ions at $m / z 35$ and 46, respectively. Observed ions were normalized to the detected quantity of the acetate reagent ion and multiplied by $8 \times 10^{5}$, resulting in signal units of normalized counts, as we have previously reported for the detection of these analytes (VandenBoer et al., 2013). The signal from the CIMS was averaged to a $1 \mathrm{~min}$ time base to compare to other measurements.

In our purity and stability experiments, additional instrumentation was used to detect $\mathrm{HONO}, \mathrm{NO}_{y}$, and other reactive gases. A time-of-flight (ToF) chemical ionization mass spectrometer utilizing iodide adduct reagent ions $\left(\mathrm{I}^{-}\right.$ToF CIMS; Aerodyne Research Inc., Billerica, MA) was used to measure $\mathrm{HONO}$ and detect a wide array of other analytes (e.g., $\mathrm{ClNO}_{2}, \mathrm{HNO}_{3}, \mathrm{~N}_{2} \mathrm{O}_{5}$, etc.) in experimental gas flows. Specific operational details of the $\mathrm{I}^{-}$ToF CIMS for these atmospheric species are presented elsewhere (Neuman et al., 2016; Veres et al., 2020). A broadband cavity-enhanced absorption spectrometer (ACES) was used to measure HONO and $\mathrm{NO}_{2}$ (Min et al., 2016), and a single-photon laserinduced fluorescence (LIF) instrument was used to measure NO (Rollins et al., 2020). A high-sensitivity chemiluminescent $\mathrm{NO}$ instrument fitted with a gold catalyst $\left(\mathrm{NO}_{y} \mathrm{O}_{3}\right)$ was used to quantify $\mathrm{NO}$ and $\mathrm{NO}_{y}$ (Fahey et al., 1985; Fontijn 
et al., 1970; Ridley and Grahek, 1990; Ridley and Howlett, 1974; Ryerson et al., 1999).

\section{HONO calibration source characterization}

\section{1 $\mathrm{NaNO}_{2}$-coated reaction device}

Previous calibration methods required a $1-2 \mathrm{~g}$ bed of loose crystalline $\mathrm{NaNO}_{2}$ to generate high mixing ratios of $\mathrm{HONO}$ but only consumed a minimal amount of $\mathrm{NaNO}_{2}$ from the total supply before being thrown away (Febo et al., 1995; Roberts et al., 2010). At maximum, our $\mathrm{NaNO}_{2}$-coated PFA reaction devices could contain up to $60 \mathrm{mg}$ of $\mathrm{NaNO}_{2}$ ( $3.0 \mathrm{~mL} \times 20 \mathrm{~g} \mathrm{~L}^{-1} \mathrm{NaNO}_{2}$ coating solution) or $40 \mathrm{mg}$ of $\mathrm{NO}_{2}^{-}$if there was $100 \%$ coating efficiency. Due to the hydrophobic nature of PFA and the loss of liquid solution from the drying procedure, however, the reaction device retained only a fraction of the applied $\mathrm{NaNO}_{2}$. The amount of $\mathrm{NO}_{2}^{-}$ present after coating the PFA devices $(n=3)$ was determined by rinsing with deionized water and analysis by IC-CD. An average mass of $0.53 \pm 0.27 \mathrm{mg} \mathrm{NO}_{2}^{-}$was deposited on the surface of the PFA device $-1.3 \%$ of the total $\mathrm{NO}_{2}^{-}$applied. The quantity coated on the PFA devices was sufficient to generate stable, low mixing ratios of HONO for extended periods. To efficiently use most of the salt, we calculated how long the $\mathrm{NaNO}_{2}$ coating could provide a specific calibration mixing ratio of HONO (Eq. 1). Thus, we designed and operated our coated devices based on their calculated capacity to generate a specific mixing ratio of $\mathrm{HONO}\left(C_{\mathrm{HONO}}\right)$ continuously over time based on the number of moles of $\mathrm{NaNO}_{2}$ deposited in the coating $\left(n_{\mathrm{NaNO}_{2}}\right)$ and the total dilution flow in moles of air for that same duration $\left(F_{\text {air }}\right)$.

$C_{\mathrm{HONO}}=n_{\mathrm{NaNO}_{2}} / F_{\text {air }}$

To generate higher mixing ratios of $\mathrm{HONO}$, more $\mathrm{NaNO}_{2}$ mass and/or coated surface area are required. The higher surface area of a coated glass annular denuder housed in Tefloncoated aluminum tubing was explored for use as an alternative to PFA tubing. To test this, three annular denuders were prepared using the same volume of coating solution. An average mass of $7.26 \pm 1.80 \mathrm{mg}$ of $\mathrm{NaNO}_{2}$ on the denuder surface was determined $-18 \%$ of the total applied. Thus, the coated annular denuder resulted in about 18 times more deposited $\mathrm{NaNO}_{2}$ than the PFA devices, due to the higher available surface area of pattern-etched glass. Unfortunately, these devices proved unstable, as discussed below, and are expensive. The HONO output from other tubing materials was also tested (Sect. 3.7.2).

The lifetime of the $\mathrm{NaNO}_{2}$ devices can be approximated using Eq. (1), under the assumption that a stable output of HONO is generated from the start of the experiment. At standard room temperature and pressure a device generating $2 \mathrm{ppbv}$ of $\mathrm{HONO}$ and containing the average $0.53 \mathrm{mg}$ of $\mathrm{NO}_{2}^{-}$observed for the PFA device could last for up to
$88 \mathrm{~d}$. In practice, we observed a PFA device generating approximately 2 ppbv $\mathrm{min}^{-1}$ of $\mathrm{HONO}$ to be reliable for over 4 weeks during experiments performed to test the stability and reproducibility of the PFA devices (Sect. 3.5, 3.6). The lifetime of the device is expected to decrease proportionally if a higher output of $\mathrm{HONO}$ for a given mass of $\mathrm{NaNO}_{2}$ coating is required. Decreasing HONO mixing ratios on the order of a hundred pptv on hourly timescales (for an initial few ppbv of output) was used as a metric to indicate that coated reaction devices were depleted since their output was no longer stable.

\subsection{HONO generation with water vapor}

Prior calibration sources have exclusively reported HONO production via the acid displacement mechanism. In the mass balance experiments reported below, where we employ this mechanism, it was discovered that water vapor alone was responsible for a measurable amount of the generated HONO in the ppbv regime. Mixing ratios of HONO produced using our coated PFA reaction devices exposed to water vapor were too low to accurately measure using our $\mathrm{NO}_{x}$ analyzer $(\leq 0.6 \mathrm{ppbv})$. To explore the influence of water vapor (i.e., humid air) on HONO output, we performed a series of experiments at different $\mathrm{RH}$ using an $\mathrm{NaNO}_{2}$-coated annular denuder. The denuder generated higher HONO mixing ratios, on the order of several ppbv in 1.1 SLPM. Prior to the experiments, the calibration source unit was flushed with zero air for at least $12 \mathrm{~h}$. The absence of $\mathrm{HCl}(<5 \mathrm{pptv})$ was confirmed with the CRDS. When the RH passing through the denuder was $0 \%$ we observed no HONO, with signal near the detection limit of the $\mathrm{NO}_{x}$ analyzer $(0.50 \pm 0.48 \mathrm{ppbv}$, $n=43$ ). When we increased the RH of the carrier gas, we observed the production of HONO, but the variation was not monotonic. At a RH of $25 \%$ HONO output increased to $11.73 \pm 0.39 \mathrm{ppbv}(n=35)$ followed by a decrease at an RH of $50 \%$ to $8.60 \pm 0.63 \mathrm{ppbv}(n=38)$. This trend is likely due to the effective Henry law constant of HONO in the aqueous film on the surface of the $\mathrm{NaNO}_{2}$ device, due to the weak acid nature of $\mathrm{HONO}\left(\mathrm{pK}_{\mathrm{a}}=3.4\right)$. When the humidity is higher, less HONO may be released from the surface due to the increased presence of water in which a larger equilibrium concentration of aqueous nitrite can be sustained. This contrasts with $\mathrm{HCl}\left(\mathrm{pK}_{\mathrm{a}}\right.$ of -8$)$, which completely dissociates in aqueous solution on the surface of the $\mathrm{NaNO}_{2}$ device and facilitates the acid displacement mechanism (Reaction R2).

This is the first observation of water-vapor-produced HONO. Prior calibration sources typically generated very high HONO mixing ratios from 100 ppbv up to tens of ppmv in the displacement vessel, resulting in the contribution from humid air being undetected (Febo et al., 1995; Gingerysty and Osthoff, 2020; McGrath et al., 2019; Roberts et al., 2010; VandenBoer et al., 2015; Zhou et al., 2018). The observed HONO mixing ratios from this mechanism in our experiments would likely be within the error of the mass balance 
calculations or indistinguishable from noise in the analytical instrumentation in prior reports. Our results suggest that the use of water vapor passed over a $\mathrm{NaNO}_{2}$-coated PFA reaction device produces sub-ppbv mixing ratios of HONO for calibration of instruments making ambient observations in remote environments. Using water vapor alone, the only way to increase the HONO mixing ratios from the calibration system is to increase the available amount of $\mathrm{NaNO}_{2}$, which is challenging (Sect. 3.1 and 3.7.2). A more controlled approach to reach higher mixing ratios is through the acid displacement technique.

\subsection{HCl emissions from custom-built PDs}

To generate stable $\mathrm{HONO}$ mixing ratios using an $\mathrm{NaNO}_{2}$ reaction device on the order of a few to tens of ppbv, a stable source of $\mathrm{HCl}$ is required. The $\mathrm{HCl}$ generated from custommade PDs was therefore evaluated as a function of solution concentration contained $(1.2-6 \mathrm{M})$, temperature $\left(30-60^{\circ} \mathrm{C}\right)$, and stability by CRDS (Table 1, Fig. S6). Custom-made PDs of different concentration and lengths were tested for their ability to produce a range of HONO mixing ratios. Custom-made PDs have been previously demonstrated in our work to provide a stable emission source of $\mathrm{HCl}$ (MacInnis et al., 2016). The $\mathrm{HCl}$ output was found to be temperature dependent and increased exponentially with temperature, as expected from theory (Sect. S2). However, as the PD was ramped to higher temperatures $\left(>50^{\circ} \mathrm{C}\right)$ the permeation rate became more unstable, with a resulting settling time of about $1 \mathrm{~h}$ as the materials from the permeation oven apparatus re-equilibrated (Fig. S7). Since the $\mathrm{HCl}$ PDs were observed to be most stable at 30 and $40^{\circ} \mathrm{C}$, these temperatures were considered optimal to generate the stable HONO mixing ratios. Note that the HONO mixing ratios in the $100 \mathrm{sccm}$ flow exiting the reaction device range from 9.7 to $72 \mathrm{ppbv}$ (Table 1), which are much lower than all prior calibration sources, enabling easy dilution to reach environmentally relevant HONO mixing ratios for instrument calibration or experimental applications.

Two newly made $6 \mathrm{M} \mathrm{HCl}$ PDs (PD-6b and PD-6c) were found to emit different, yet highly stable (e.g., $\pm 0.01 \mathrm{ppbv}$ ), mixing ratios at identical oven temperatures (Fig. S6). This demonstrates potential variability with each new device due to inconsistent results during custom fabrication compared to commercial PDs. The most likely source of such differences in output is variability in our sealing of the PTFE plugs resulting in increased emission rates. In any case, the PDs remain stable with less than $10 \%$ relative standard deviation. In comparison, commercial-device emission rates are often certified within $\pm 30 \%$. The emission rates of commercial PDs are certified through measurement by gravimetric weight loss over time $\left(\mathrm{ng} \mathrm{min}^{-1}\right)$. A commercial $1 / 4$ in. $(64 \mathrm{~mm})$ Teflon $\mathrm{HCl}$ PDs of $6.55 \mathrm{M}$, certified to emit $1905 \pm 520 \mathrm{ppbv}$ in $100 \mathrm{sccm}$ flow at $40^{\circ} \mathrm{C}$ (relative standard deviation, $\mathrm{RSD}=27.3 \%$; VICI Metronics, Inc.; Poulsbo,
WA), has this output variance due to the coemission of water and propagated measurement uncertainties. A lower variance in the emitted $\mathrm{HCl}$ was observed from our custom-made PDs when we quantified $\mathrm{HCl}$ directly by either CRDS or ICCD. Custom-built PDs were therefore chosen over commercial PDs due to their demonstrated stability and low cost. It was found that $\mathrm{HCl}$ outputs of the custom-PDs slowly diminished over time, which emphasizes the need for regular calibrations. For example, the $\mathrm{HCl}$ output from 2-year-old PD-6a emitted $0.21 \pm 0.01$ ppbv in 1.1 SLPM in comparison to $2.0 \pm 0.01 \mathrm{ppbv}$ when it was newly made, which decreased the resulting HONO generation in the reaction device. Similar results have been observed in calibrations with PDs of aqueous $\mathrm{NH}_{3}$ and $\mathrm{HNO}_{3}$ solutions decreasing by $\sim 30 \%$ during 2 years of storage, as well as for carbonyl sulfide (Fried et al., 1998; Neuman et al., 2003). Despite the decreasing $\mathrm{HCl}$ output over a year or more of use, $\mathrm{HCl}$ PDs act as a stable acid source on the order of weeks, producing consistent $\mathrm{HCl}$ output to subsequently generate stable $\mathrm{HONO}$, even when removed from the permeation oven or stored for up to 2 months. Overall, it is difficult to replicate PD emission rates using the same $\mathrm{HCl}$ concentration and material dimensions for a custom-made PD. The custom-built PD seals can be altered by replacing the PTFE plug by crimping the ends of heated-to-pliability PFA tubing to form welded polymer ends (Sect. S2). Such an approach is expected to improve the reproducibility of the custom-device emission rates but is beyond the scope of this work to explore in more detail.

\subsection{Acid displacement to generate HONO}

Two techniques were used to assess the reaction completion between $\mathrm{HCl}$ and $\mathrm{NaNO}_{2}$ in the calibration system. We applied a mass balance approach that combined the CRDS measurement of $\mathrm{HCl}$, our $\mathrm{NO}_{x}$ analyzer $\mathrm{HONO}$ measurement, and IC-CD quantitation of these acids scrubbed into $1 \mathrm{mM}$ $\mathrm{NaOH}$. The displacement efficiency was further confirmed by simultaneous observation of $\mathrm{HCl}$ and $\mathrm{HONO}$ by acetate quadrupole CIMS.

\subsubsection{Mass balance of HONO generated}

Experiments were conducted to confirm that $\mathrm{HONO}$ can be generated by introducing only humid air $(50 \% \mathrm{RH})$ within the $\mathrm{NaNO}_{2}$ devices without the presence of $\mathrm{HCl}$. In humid air, we observed HONO levels above the detection limit (DL) of the $\mathrm{NO}_{x}$ analyzer. A single PFA device exposed to humid air $(50 \% \mathrm{RH})$ released up to $0.61 \mathrm{ppbv}$ of $\mathrm{HONO}$ - equivalent to $77 \%$ of the total HONO generated when coupled with an $\mathrm{HCl}$ PD (Table 2). The reaction of the humidified $\mathrm{NaNO}_{2}$-coated device, resulting in the release of $\mathrm{HONO}$, implies formation of $\mathrm{NaOH}$. Further speculation on the reaction mechanism is beyond the scope of this work. Given the existing challenge in producing low mixing ratios of HONO in the pptv range, it appears that these can be reached most 
easily without the use of an HCl PD in our calibration system, while higher mixing ratios necessitate the addition of $\mathrm{HCl}$ (Sect. 3.7). The $\mathrm{NO}_{x}$ analyzer signal was indistinguishable from zero when the $\mathrm{NaNO}_{2}$ reaction device was absent, but all other conditions were matched. This demonstrates that HONO was generated only within the $\mathrm{NaNO}_{2}$ reaction device.

The total flow for all mass balance experiments was 1.1 SLPM (Fig. 1) with zero air flows replacing those typically carrying reagents when they were removed. We observed that the HONO output from the reaction devices was greater than the $\mathrm{HCl}$ input from the PDs, confirming that another chemical reaction was generating the remaining $\mathrm{HONO}$ (Table 2). Mass balance could only be achieved when accounting for the $\mathrm{HONO}$ generated by the $\mathrm{NaNO}_{2}$ exposed to humid air $(\sim 50 \% \mathrm{RH})$. No other acidic or ionic contaminants were present in $\mathrm{NaNO}_{2}$ reaction devices or the $\mathrm{HCl}$ PDs when scrubbed solutions were analyzed by IC-CD. Therefore, other $\mathrm{NO}_{y}$ species that could have biased the $\mathrm{NO}_{x}$ analyzer measurement high were judged to be absent, and pure $\mathrm{HONO}$ was generated (i.e., only $\mathrm{NO}_{2}^{-}$was enhanced in calibration system flows scrubbed into $1 \mathrm{mM} \mathrm{NaOH}$ ). Further investigation of the system HONO purity is presented in Sect. 3.7.3, which further supports this conclusion. The remainder of the HONO output from $\mathrm{NaNO}_{2}$ devices quantitatively matched the $\mathrm{HCl}$ input to the reaction device in dry air after accounting for the water vapor production route. No $\mathrm{HCl}$ was observed to exit the devices, indicating unit acid displacement efficiency and reaching mass balance.

\subsubsection{CIMS measurements}

Confirmation of these observations with the quadrupole CIMS provided higher time resolution observations of $\mathrm{HONO}$ and $\mathrm{HCl}$ simultaneously. The ions monitored were $m / z 35\left(\mathrm{Cl}^{-}\right)$for $\mathrm{HCl}$ and $46\left(\mathrm{NO}_{2}^{-}\right)$for $\mathrm{HONO}$ (Fig. 2). The instrumental sensitivity to these two analytes is similar under this ionization scheme (VandenBoer et al., 2013). The HONO calibration source was stabilized for $2 \mathrm{~h}$ before the gas stream was introduced to the CIMS. Zero measurements were taken for $15 \mathrm{~min}$ before and after the measurements to correct for background drift in the $m / z 46$ signal. Upon sampling the output of the HONO calibration source the signal at $m / z 46$ rapidly increased (Fig. 2). The signal of $\mathrm{Cl}^{-}$at $m / z 35$ was below the detection limit throughout this period, confirming again that the $\mathrm{HCl}$ from the PD was entirely consumed by the $\mathrm{NaNO}_{2}$ reaction device throughout the measurement period, consistent with the experiments presented above where no $\mathrm{HCl}$ was measured by the CRDS. Overall, the results from these assessments indicate that the HONO calibration source is generating HONO with a one-toone displacement efficiency by $\mathrm{HCl}$, consistent with this observation from other HONO calibration sources using higher quantities of $\mathrm{HCl}$ in a salt bed (Febo et al., 1995; Roberts et al., 2010), and the remainder originating from the water vapor reaction.

\subsection{Stability of HONO production}

The time required to achieve stable HONO signals was tested by inserting $\mathrm{HCl}$ PD-6a and the new $\mathrm{NaNO}_{2}$ PFA reaction device into the calibration system, followed by flow start-up. Stable HONO signals were observed within $7 \mathrm{~h}$ of powering on the HONO calibration system. This is $5 \mathrm{~h}$ longer than required to reach stable mixing ratios for a previously stabilized $\mathrm{NaNO}_{2}$ device. Three trials using newly coated $\mathrm{NaNO}_{2}$ reaction devices and PD-6a, once stabilized, generated an average HONO output of $2.28 \pm 0.58 \mathrm{ppbv}$, which corresponds to an RSD of $24 \%$ between runs and a relative standard error (RSE) of $3 \%(n=2367$; Fig. 3$)$. The noise observed in the stabilized HONO output in Fig. 3 can be primarily attributed to the noise associated with the $\mathrm{NO}_{x}$ analyzer detector (18 of the $24 \%$; DL $=0.4 \mathrm{ppbv} ; 1$ min average). This conclusion is supported by the lower noise in $\sim 2.5 \mathrm{ppbv}$ HONO mixing ratios observed by the CIMS (Fig. 2, RSD of $8.1 \%$ ), ACES (RSD $8.2 \%$ ), and $\mathrm{NO}_{y} \mathrm{O}_{3}$ (RSD $1.9 \%$ ). In these added observations with higher sensitivity instrumentation, the stability was equal to instrumental precision. This represents a major improvement over our previously reported calibration sources with potential for $30 \%$ variability at a minimum (VandenBoer et al., 2013; Zhou et al., 2018).

However, when the $\mathrm{HCl}$ output from PDs is unstable, this can interfere with the stability of the HONO generated because it is dependent on acid displacement. A common characteristic of our custom-made PDs monitored by real-time CRDS measurements is short-duration increases in output over minutes up to $1 \mathrm{~h}$, due to reduced emission of $\mathrm{H}_{2} \mathrm{O}$ and increased emission of $\mathrm{HCl}$, resulting in transient pulses from the device (Fig. 4a). The anticorrelation between $\mathrm{HCl}$ and $\mathrm{H}_{2} \mathrm{O}$ is expected for a constant mass emission to result from the contained aqueous solution. A corresponding rapid increase in HONO production results from such occurrences (Fig. 4b).

Commercial PD manufacturers evaluate average mass emission rates by gravimetric weight loss over several weeks at $40^{\circ} \mathrm{C}$ for certification, which could include such shortterm events. The HONO output from a newly made custommade $\mathrm{HCl}$ PD (PD-6c) over four consecutive observation periods upon insertion of a new $\mathrm{NaNO}_{2}$ reaction device (Runs $1-4)$ at constant temperature $\left(40^{\circ} \mathrm{C}\right)$ shows that the new custom-made PD requires about 1 week of operation before its output is stable (Fig. $4 \mathrm{~b}-\mathrm{c}$ ). Therefore, careful preparation of PDs and $\mathrm{NaNO}_{2}$ reaction devices in advance of extensive use will yield a HONO calibration source with the fastest stabilization times possible for continuous operation over a period of months. Note again that the HONO measurements for Fig. $4 \mathrm{~b}-\mathrm{c}$ were performed several months before the $\mathrm{HCl}$ emission rates for PD-6c presented in Table 1 were obtained, 
Table 2. Mass balance of measured mixing ratios of $\mathrm{HCl}$ entering and $\mathrm{HONO}$ exiting the calibration source to determine acid displacement efficiency (ADE) at $50 \% \mathrm{RH}$ and $40^{\circ} \mathrm{C}$. Uncertainties represent $1 \sigma$ standard deviation from the mean for $\geq 30$ min of measurements and $1 \sigma$ propagated error for calculated values.

\begin{tabular}{lrrrrr}
\hline PD & $\begin{array}{r}\mathrm{HCl}_{\mathrm{IN}} \\
(\mathrm{ppbv})\end{array}$ & $\begin{array}{r}\mathrm{HONO} \text { from } \\
\mathrm{HCl}+\mathrm{H}_{2} \mathrm{O}(\mathrm{ppbv})\end{array}$ & $\begin{array}{r}\mathrm{HONO} \text { from } \\
\mathrm{H}_{2} \mathrm{O}(\mathrm{ppbv})\end{array}$ & $\begin{array}{r}\mathrm{HONO} \text { from } \\
\mathrm{H}_{2} \mathrm{O}(\%)\end{array}$ & $\begin{array}{r}\text { ADE } \\
(\%)\end{array}$ \\
\hline PD-6a & $0.08 \pm 0.002$ & $0.31 \pm 0.15$ & $0.24 \pm 0.14$ & $77 \pm 45$ & $>99$ \\
PD-6b & $2.2 \pm 0.011$ & $2.78 \pm 0.41$ & $0.61 \pm 0.44$ & $22 \pm 16$ & $>99$ \\
\hline
\end{tabular}

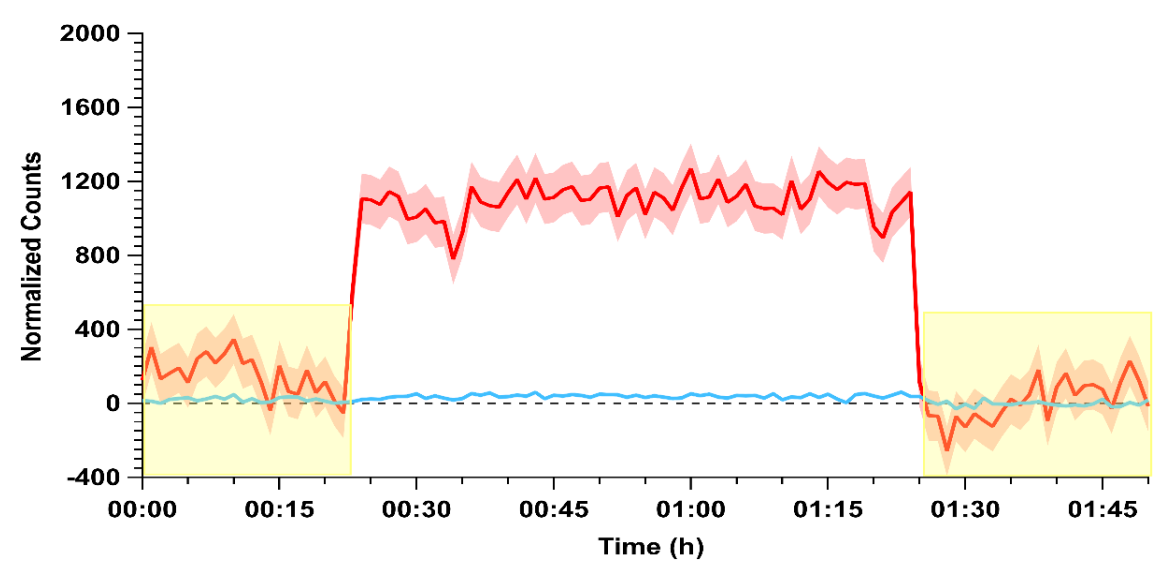

Figure 2. Conversion efficiency of $\mathrm{HCl}$ (blue) to $\mathrm{HONO}$ (red) via the acid displacement reaction on a $\mathrm{NaNO}_{2}$ reaction device. The $\mathrm{HCl}$ PD-6a and one coated PFA device were used and measured following $2 \mathrm{~h}$ of stabilization. The acids were observed by acetate quadrupole CIMS with time resolution of $0.50 \mathrm{~s}$ and averaged to $60 \mathrm{~s}$. Yellow shaded regions indicate the addition of zero air to the instrument inlet for background correction, while red and blue shaded regions correspond to $1 \sigma$ variance in the observations. Note that the variance in the $\mathrm{HCl}$ trace is similar to the width of the line.

resulting in high HONO mixing ratios produced in these experiments.

\subsection{Reproducibility and robustness}

The HONO calibration system was designed to not only be stable, but also reproducible in its output of HONO for a given $\mathrm{PD}$ and any $\mathrm{NaNO}_{2}$ reaction device, resulting in robust portability. We tested the reproducibility, and therefore robustness, of the HONO calibration system by putting it through a series of experiments designed to simulate transport to, and use in, the field. Further assessments of its reproducibility by measuring the output with different $\mathrm{NaNO}_{2}$ reaction devices and $\mathrm{HCl}$ PDs were also made.

\subsubsection{Field transport simulations}

Simulations of field transportation subjected the system to full disassembly and reassembly of the acid displacement and permeation oven setup. In addition, for some experiments the calibration unit was transported on a lab cart over very rough flooring to simulate vibrations experienced for real use when transported using rolling carts, mobile labs, or aircraft. For the first eight simulations PD-6a and one $\mathrm{NaNO}_{2}$-coated reaction device were used over several weeks (see Table S1 for further detail). Following reassembly after the field trans- port simulations, the HONO calibration source was restarted, the system was equilibrated for $2 \mathrm{~h}$, and then its output was measured by the $\mathrm{NO}_{x}$ analyzer (Fig. 5). $\mathrm{An} \mathrm{Na}_{2} \mathrm{CO}_{3}$-coated annular denuder was incorporated into the middle of five of the eight trial experiments for $1 \mathrm{~h}$ to determine whether any $\mathrm{NO}_{x}$ was being generated between restarts and its associated variability (FS1-FS5; Table S1). No measurable $\mathrm{NO}_{x}$ was detected in any of these experiments.

The average HONO mixing ratio within the eight field transport simulations (FS) ranged from 1.68 to $2.51 \mathrm{ppbv}$. The HONO output across all eight field simulations had an average of $2.07 \pm 0.48 \mathrm{ppbv}(\mathrm{RSD}=24 \%$; $\mathrm{RSE}=2 \%$, $n=218$ ). These measurements used a single $\mathrm{NaNO}_{2}$ reaction device over 5 weeks of continuous operation, after which the depletion of $\mathrm{NaNO}_{2}$ resulted in a decline of HONO mixing ratios. These HONO mixing ratios are similar to the average HONO output of $2.28 \pm 0.58 \mathrm{ppbv}$ (RSD of $24 \%$, RSE of $3 \%, n=2367$ ) from the previous measurements with PD6a (Fig. 3), which were not subject to field simulations but did use freshly coated $\mathrm{NaNO}_{2}$ reaction devices. The generated HONO mixing ratios varied most between our early experiments (FS1-FS4; RSD $\geq 24 \%$ ), when first gaining experience in ensuring gas-tight connections throughout the calibration system, with improvement clearly emerging over time (FS4-FS8; RSD $\leq 10 \%$ ). The RSE values of field trans- 


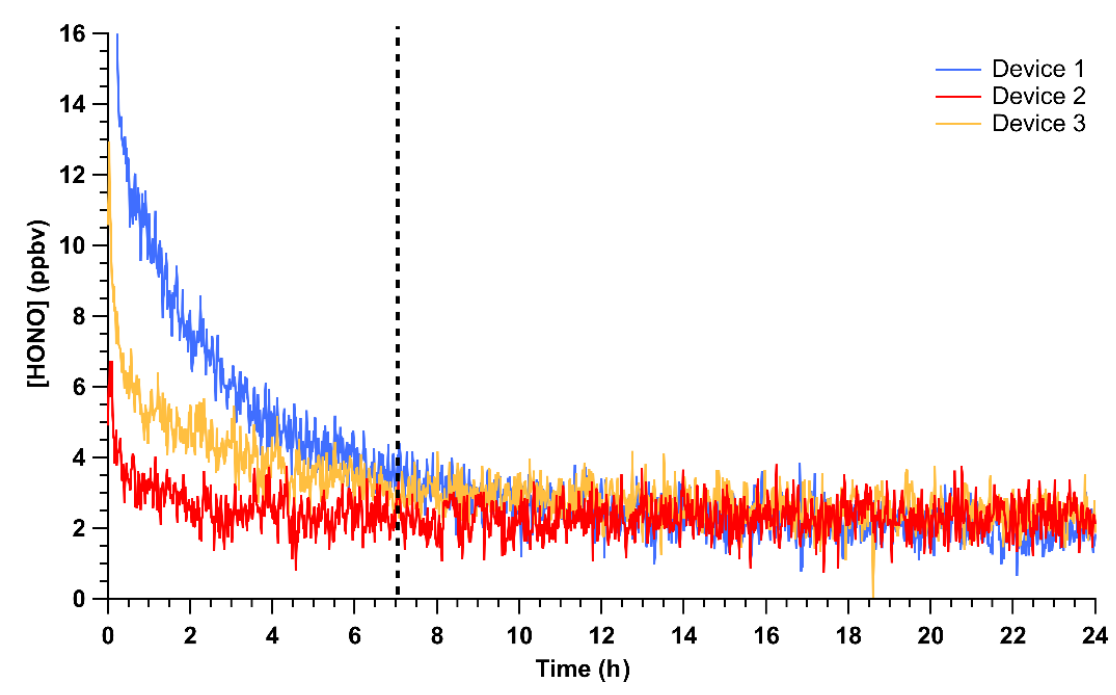

Figure 3. Mixing ratios of $\mathrm{HONO}$ observed using $\mathrm{HCl} \mathrm{PD}-6 \mathrm{a}$ and three different, but freshly coated, $\mathrm{NaNO}_{2}$ PFA reaction devices. Time zero indicates the start of HONO production in the calibration unit where no prior flow through the calibration unit existed, but all temperatures were stable at $40^{\circ} \mathrm{C}$. The vertical dashed line denotes the time where the outputs of the three devices are no longer statistically different from each other. Reported measurements are 1 min average data with a $30 \mathrm{~s}$ Kalman filter on the $\mathrm{NO}_{x}$ analyzer.

port simulations had a lower RSE of $1 \%$ compared to $3 \%$ for the experiments that were stationary (Fig. 5), likely due to the reuse of the same $\mathrm{NaNO}_{2}$ reaction device. This demonstrates that the HONO calibration source can robustly generate a reproducible mixing ratio output within $25 \%$ of the mean during each system reconstruction if the same $\mathrm{HCl}$ PD is used. It is worth noting here again that most of the variance observed in HONO mixing ratio output within any of the presented trials derives from the precision of our $\mathrm{NO}_{x}$ analyzer detector (Sect. 3.5).

\subsubsection{Factors affecting reproducibility of $\mathrm{HCl}$ input}

As shown in Table 1, PDs made with the same $\mathrm{HCl}$ concentration $(6 \mathrm{M})$ and similar dimensions did not lead to the same HONO output, due to variability in the $\mathrm{HCl}$ emission rates. While it is possible for custom-made PDs to have similar $\mathrm{HCl}$ emissions and therefore $\mathrm{HONO}$ output (when using the same $\mathrm{NaNO}_{2}$ device), it is difficult to achieve in practice. When making a new PD as per the methods described in Sect. S2, it can be difficult to replicate because the emission rate depends on the effectiveness of the plug seal. For this reason, one cannot simply make a $\mathrm{HCl}$ PD with plugs using the same concentration and material dimensions and necessarily expect the same output. We present an alternative Teflon welding method to overcome this limitation in Sect. S2, which has been successfully used for generation of VOC PDs. Regardless, the output of new HCl PDs should be quantified prior to use and not subject to extreme conditions to ensure the polymer permeability is retained.

The reproducibility of $\mathrm{HONO}$ output using a stable $\mathrm{HCl}$ PD is shown in Fig. 5. The observed HONO output ranged from 1.68 to $2.51 \mathrm{ppbv}(n=8, \mathrm{RSD}=24 \%)$. We next tested the reproducibility for newly made $\mathrm{HCl}$ PDs. Two experiments used PD-6b, containing 6 M HCl (Fig. S10). After a period of stabilization, the two experiments generated similar HONO mixing ratios $(2.58 \pm 0.43 \mathrm{ppbv}$ after $25 \mathrm{~h}, \mathrm{RSD}=16.5 \%, \mathrm{RSE}=1.43 \%, n=792)$. The spikes in HONO output at 15 and $21 \mathrm{~h}$ in the second experiment (green trace, Fig. S10) were likely due to pulses of $\mathrm{HCl}$, which we commonly observed with new PDs (e.g., Fig. 4a-b). This emphasizes our recommendation that new custom-made $\mathrm{HCl}$ PDs should be used for an extended period prior to use for acid displacement to ensure the emission rate has stabilized.

We made another PD with $1.2 \mathrm{M} \mathrm{HCl}$, as it emits less $\mathrm{HCl}$ in comparison to a PD made with $6 \mathrm{M} \mathrm{HCl}$ (Table 1), to determine the reproducibility in HONO output at lower mixing ratios. Across three experiments using a previously stabilized $\mathrm{NaNO}_{2}$ device, an output of 0.69-1.12 ppbv (RSD $=53.7 \%$, $\mathrm{RSE}=4.52 \%, n=143$ ) was observed (Fig. S11). The high RSD is due to instrument noise as the HONO output approached the detection limit of the $\mathrm{NO}_{x}$ analyzer $(0.4 \mathrm{ppbv})$. Nonetheless, a stable output of HONO was achieved within $2 \mathrm{~h}$ after starting the calibration system, similar to our previous results (Fig. 5). As long as a new custom-made HCl PD has been allowed adequate time to stabilize under a gas flow at constant temperature (ideally $7 \mathrm{~d}$ ), a stable HONO output can be easily replicated within $2 \mathrm{~h}$ of starting the resulting HONO calibration system. We recommend quantifying the $\mathrm{HCl}$ emissions prior to use if the PD has been stored for a long period or been subjected to extreme conditions.

\subsection{Adjusting and controlling HONO mixing ratios}

Increasing the mixing ratio of $\mathrm{HCl}$ and the type and quantity of $\mathrm{NaNO}_{2}$ reaction devices connected in series were explored 

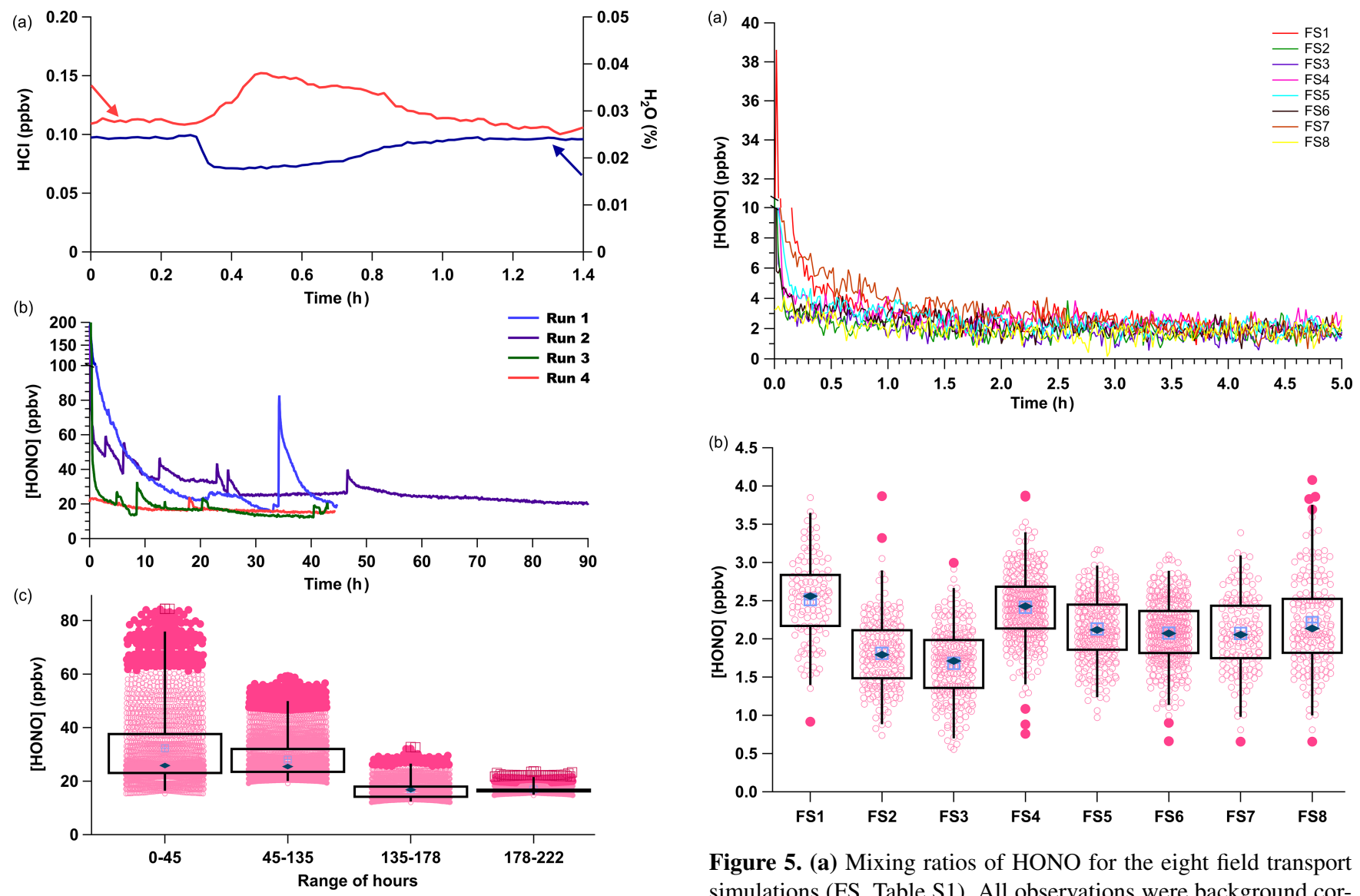

Figure 4. (a) CRDS high-resolution observation for an $\mathrm{HCl}$ emission pulse (red) and $\mathrm{H}_{2} \mathrm{O}$ decrease (blue) from PD-6a resulting in a $50 \%$ increase in the $\mathrm{HCl}$ mixing ratio emitted. (b) Time series of four consecutive measurement periods of HONO production, using only PD-6c and a new $\mathrm{NaNO}_{2}$-coated reaction device in each run. (c) Box (first and third quartile) and whiskers ( $3 \sigma$ from the mean) of HONO mixing ratios observed for the four runs are binned by duration of use for each new reaction device in hours. Mean values are indicated with a filled dark blue diamond marker, median values by the light blue crossed box marker, dark pink circles are $2 \sigma$ outliers, and dark red squares $3 \sigma$ outliers.

as methods to adjust the HONO mixing ratio exiting the calibration system.

\subsubsection{Temperature control}

The HONO calibration system was designed to be tunable by adjusting the oven temperature. $\mathrm{HCl}$ emissions increased with increasing temperatures $\left(30-60{ }^{\circ} \mathrm{C}\right.$, Fig. S6). The HONO mixing ratios increased exponentially with increasing oven temperatures (Table 3 and Fig. S12). Very low levels of $\mathrm{HCl}$ exited the $\mathrm{NaNO}_{2}$ device ( $\leq 3 \%$ of $\mathrm{HCl}$ input), which demonstrated that there was continued near-unity acid displacement efficiency. With increasing temperature of the $\mathrm{NaNO}_{2}$ reaction device in the presence of water vapor, a sim- 
Table 3. Average mixing ratios of $\mathrm{HCl}$ input (PD-6a), and $\mathrm{HONO}$ emitted from reaction with water vapor and with both reagents as a function of temperature. Uncertainty denotes $1 \sigma$ standard deviation from the mean of measured values.

\begin{tabular}{lrrr}
\hline $\begin{array}{l}\text { Temperature } \\
\left({ }^{\circ} \mathrm{C}\right)\end{array}$ & $\mathrm{HCl}(\mathrm{ppbv})$ & $\begin{array}{r}\mathrm{HONO} \text { from } \\
\mathrm{H}_{2} \mathrm{O}(\mathrm{ppbv})\end{array}$ & $\begin{array}{r}\text { Total HONO } \\
(\mathrm{ppbv})\end{array}$ \\
\hline 30 & $0.230 \pm 0.003$ & 0.3 & $0.5 \pm 0.4$ \\
40 & $0.330 \pm 0.007$ & 0.7 & $1.0 \pm 0.5$ \\
50 & $0.660 \pm 0.037$ & 1.3 & $2.0 \pm 0.5$ \\
\hline
\end{tabular}

Table 4. Average measured HONO mixing ratios (ppbv) using different $1 / 2$ in. inner diameter tubing. All results are at $40^{\circ} \mathrm{C}$ and using same $\mathrm{HCl} \mathrm{PD}$ (PD-6c). Variability shown is $1 \sigma$ from the mean.

\begin{tabular}{lr}
\hline Device material & HONO (ppbv) \\
\hline PFA & $6.20 \pm 0.50$ \\
Etched PFA & $5.68 \pm 0.71$ \\
Stainless steel & $6.75 \pm 0.83$ \\
Nylon & $6.06 \pm 0.61$ \\
Quartz & $3.72 \pm 0.55$ \\
\hline
\end{tabular}

as the PFA devices (Sect. 2.1) to see if there was an improvement in output stability or increased emissions of HONO. The materials used were all cylindrical tubing with $1 / 2 \mathrm{in}$. $(1.27 \mathrm{~cm})$ inner diameters and were of similar lengths and surface area. The different materials that were tested showed similar HONO outputs (within variability), except for quartz (Table 4). The quartz tubing gave a notably lower HONO output compared to other materials. This may have been due to a poor coating efficiency on the surface, as observed visually when making this device. This is an unexpected outcome given that quartz is more hydrophilic than PFA. That we observed similar HONO outputs for the other materials could be due to the devices having the same internal surface area coated with $\mathrm{NaNO}_{2}$, implying that $\mathrm{HONO}$ output is proportional to surface-available $\mathrm{NaNO}_{2}$. The inside of a PFA device was etched manually every few millimeters in concentric circles in an attempt to increase the surface availability of $\mathrm{NaNO}_{2}$, but no change in HONO output was observed compared to the unetched device.

Two additional methods were tested to increase the available surface area in the $\mathrm{NaNO}_{2}$ device: increasing the number of coated PFA reaction devices in series and using an annular denuder. The HONO output with two PFA devices connected in series increased when using either $2.0 \mathrm{ppbv}$ (PD$6 \mathrm{~b})$ or $5.0 \mathrm{ppbv}$ of $\mathrm{HCl}(\mathrm{PD}-6 \mathrm{c})$ at $40^{\circ} \mathrm{C}$ and $50 \% \mathrm{RH}$. We did not observe $\mathrm{HCl}$ breakthrough at the exit of the first PFA device, indicating that the increased HONO mixing ratio is the result of the water vapor reaction. We observed variability in the amount of HONO produced between the four PFA devices, ranging from 0.8 to $1.3 \mathrm{ppbv}$ per device.

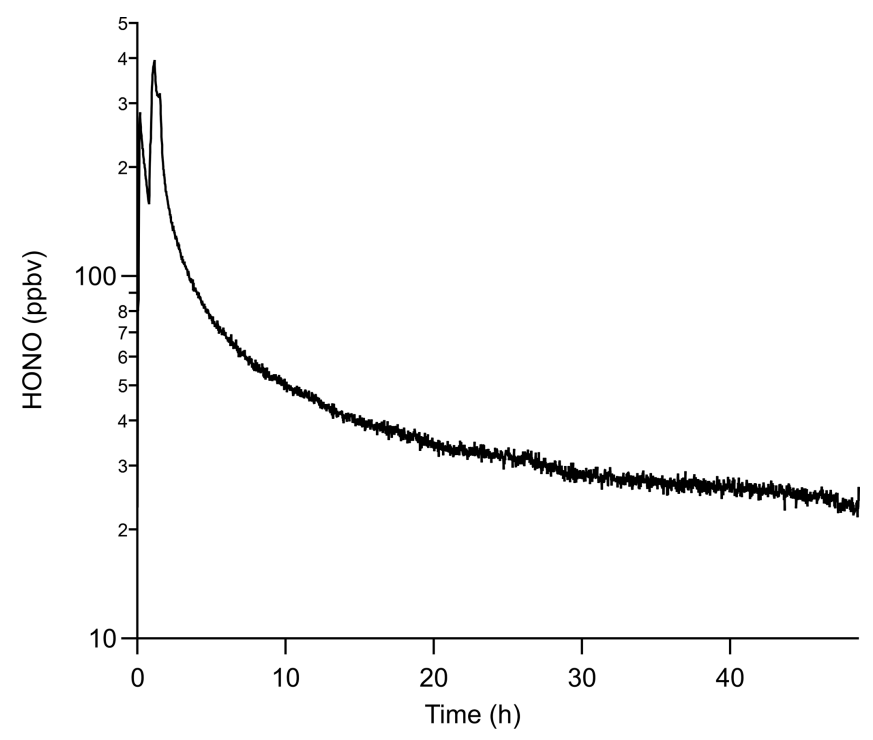

Figure 6. Mixing ratio of $\mathrm{HONO}$ produced from a $\mathrm{NaNO}_{2}$-coated annular denuder using PD-6c. Time zero is when $\mathrm{HCl}$ was first introduced to the annular denuder at $50 \%$ RH. Note that HONO mixing ratios are on a log scale.

More HONO can be generated using the same PDs in conjunction with an annular denuder, which has a larger internal surface area of $3063 \mathrm{~cm}^{2}$ compared to $388 \mathrm{~cm}^{2}$ for the PFA device. HONO emissions using PD-6c and an annular denuder produced a factor-of- 4 higher mixing ratio of $24.5 \pm 1.0 \mathrm{ppbv}$ compared to $6.2 \pm 0.5 \mathrm{ppbv}$ with a single PFA device, but it required $45 \mathrm{~h}$ to stabilize. Again, the increase is due to promotion of the water vapor reaction. The major drawback of using an annular denuder is that the output drifted to lower mixing ratios continuously at a rate of a few parts per billion by volume per hour $\left(\mathrm{ppbv} \mathrm{h}^{-1}\right)$, which was not a feature of the PFA devices (Fig. 6). The HONO output over any $4 \mathrm{~h}$ period was reasonably stable (within $0.5 \mathrm{ppbv}$ ) following the first $24 \mathrm{~h}$ of stabilization time, which suggests that a $\mathrm{NaNO}_{2}$-coated annular denuder could be viable for short duration HONO calibrations if a secondary quantitative method is available to confirm its output (e.g., a $\mathrm{NO}_{x}$ analyzer with a quantified HONO conversion efficiency). Overall, using a $\mathrm{NaNO}_{2}$-coated annular denuder can provide higher HONO outputs than using PFA devices but requires at least daily independent verification.

\subsubsection{Purity of the HONO output}

Previous work has demonstrated that there can be a notable $\mathrm{NO}_{x}$ impurity when generating HONO via the acid displacement method (Febo et al., 1995). To test the purity of the calibration source, the HONO output was analyzed by additional reactive nitrogen, $\mathrm{NO}_{x}$, and $\mathrm{NO}_{y}$ instrumentation. For these experiments, we used a $6 \mathrm{M} \mathrm{HCl} \mathrm{PD} \mathrm{and} \mathrm{two} \mathrm{PFA}$ devices in series in a $40^{\circ} \mathrm{C}$ calibration system, which was 
determined to have an output of 770 pptv of HONO. First, the output was analyzed by an $\mathrm{I}^{-}$ToF CIMS and found no evidence for any detectable amounts of other nitrogencontaining species (e.g., $\mathrm{ClNO}_{2}, \mathrm{ClNO}, \mathrm{HNO}_{3}$; Fig. S13) except for HONO (Neuman et al., 2016; Veres et al., 2020). The $\mathrm{I}^{-}$ToF CIMS is not sensitive to $\mathrm{NO}$ or $\mathrm{NO}_{2}$, so further measurements were made with our Mo catalyst $\mathrm{NO}_{x}$ analyzer, a cavity-enhanced absorption spectrometer (Min et al., 2016), and a gold-catalyst $\mathrm{NO}_{y}$ instrument (Fahey et al., 1985; Fontijn et al., 1970; Ridley and Grahek, 1990; Ridley and Howlett, 1974; Ryerson et al., 1999), which determined that $\mathrm{NO}_{2}$ impurities were at or below $10 \%$ of the generated HONO based on the detection precisions of the latter two instruments. Finally, we quantified NO impurities using a single-photon LIF instrument, which is sensitive to subpptv levels of NO (Rollins et al., 2020). We observed NO at $5.5 \%$ of the measured HONO signal (42 versus $770 \mathrm{pptv}$ ). Examination of our modified $\mathrm{NO}_{x}$ analyzer experiments using the same calibration system configuration revealed $6 \%$ NO on average compared to the observed HONO (ca. 69 ppbv), consistent with the LIF measurements. In contrast, when using a $\mathrm{NaNO}_{2}$-coated annular denuder with the same $\mathrm{HCl} \mathrm{PD}$, our modified $\mathrm{NO}_{x}$ analyzer observed $\mathrm{NO} / \mathrm{HONO}$ to decrease to $2 \%$.

Recent work, using an analogous HONO calibration system, has found high production of $\mathrm{NO}, \mathrm{NO}_{2}$, and $\mathrm{ClNO}$ ( $>10 \%$ ) when $\mathrm{HCl}$ input to loose $\mathrm{NaNO}_{2}$ was $>4 \mathrm{ppmv}$ (Gingerysty and Osthoff, 2020). We observed similarly high output of $\mathrm{NO}$ when the $\mathrm{HCl}$ input was increased to $2.4 \mathrm{ppmv}$ through the $\mathrm{NaNO}_{2}$-coated devices. Under these conditions, the impurity may be due to self-reactions of $\mathrm{HONO}$ at high mixing ratios, as seen in other packed or stirred $\mathrm{NaNO}_{2}$ salt beds (Febo et al., 1995). NO impurities at HONO mixing ratios below $100 \mathrm{ppbv}$ in the salt bed may result from other heterogeneous processes generating NO in the lower HONO production regime. It may be that such small absolute quantities of NO have been produced in all prior calibration sources but, as the mixing ratio of HONO produced has been reduced in our calibration system, that this impurity increases in a relative sense. The purity of the calibration source when generating $<100$ ppbv in the salt bed is $\geq 90 \%$ HONO, with the remainder accounted for as $\mathrm{NO}$ and/or $\mathrm{NO}_{2}$.

\subsection{Context and application}

The RSE of our stable HONO output is $<2.5 \%$ and less than previous $\mathrm{HCl}$ acid displacement calibration source adaptations (VandenBoer et al., 2013; Zhou et al., 2018). Potential reasons for the improved stability in HONO output are the stable production of $\mathrm{HCl}$ from custom-made PDs and that the calibration system presented in the current work eliminated the need for solid $\mathrm{NaNO}_{2}$ powder, which is prone to disturbance of equilibrated emissions through vibrations that can result in changes of up to a factor of 2 in mixing ratio output (VandenBoer et al., 2013; Zhou et al., 2018). The RSD values at the low HONO mixing ratios in this work are larger than reported by Febo et al. (1995), who generated much larger mixing ratios but did not specify the measurement details of their $\mathrm{NO}_{x}$ analyzer to facilitate true comparison. The greatest accuracy possible for this calibration source requires quantitation of the HONO output by a separate analytical method (e.g., IC-CD) and should not rely on the assumption that the $\mathrm{HONO}$ generated is equivalent to the $\mathrm{HCl}$ delivered into the reaction device due to the additional production mechanism driven by water vapor. While the output of this system is demonstrated to be highly reproducible with a given $\mathrm{HCl} \mathrm{PD}$, we recommend regular calibration.

\section{Conclusions}

We present a cost-effective, portable, stable, tunable, and robust gas-phase HONO calibration source. We utilised both a water vapor only, as well as its combination with the acid displacement reaction of $\mathrm{HCl}$, with sodium nitrite $\left(\mathrm{NaNO}_{2}\right)$ coated on the inner wall of a short length of PFA tubing within a machined Al-block permeation oven to produce a stable and continuous supply of high-purity gaseous HONO. We demonstrated for the first time that HONO was produced by humid air in the $\mathrm{NaNO}_{2}$ reaction device, such that the $\mathrm{HONO}$ output was consistently higher than the $\mathrm{HCl}$ input. If a HONO calibration source in the pptv range was desired, it could be achieved easily by using only humid air flowing through an $\mathrm{NaNO}_{2}$-coated reaction device. The output of this HONO calibration source spans the range of environmentally relevant mixing ratios - from pptv levels to tens of ppbv. This will allow instruments to be calibrated and/or intercompared using their standard atmospheric sampling parameters, without the need for excessive - or impossible - dilution or additional pumps, valves, and mass flow controllers.

We demonstrated that our HONO calibration system mixing ratio was tunable by adjusting the temperature of the permeation oven to control the water vapor reaction, as well as $\mathrm{HCl}$ emission rates from PDs. The HONO calibration source was designed to facilitate multiple calibrant concentrations, as the four holes in the aluminum heating block (Fig. S3) allows for the operation of parallel HONO sources if desired. The most stable HONO output was achieved using $\mathrm{NaNO}_{2}$-coated PFA devices at $40^{\circ} \mathrm{C}$, with $\mathrm{HONO}$ mixing ratios of $2.28 \pm 0.58 \mathrm{ppbv}$ (RSD of $24 \%$ and RSE of $3 \%$, $n=8)$ that were reliably reproduced following complete assembly of the system. From our wide range of instrumental observations, the output of the source appears to be constant within $\pm 10 \%$ or better. The purity of HONO source was determined to be $>90 \%$, and while lower than previous work (99.5\%; Febo et al., 1995) this may be a consequence of previously unseen side reactions of increasing importance at the low HONO mixing ratios generated. We consider this an acceptable trade-off for a robust field-deployable HONO source unit. The resulting system can be disassembled, trans- 
ported, and reassembled to produce the same HONO mixing ratios reproducibly, without the need for regular maintenance - where the same PD is retained between rebuilds. Custommade $\mathrm{HCl}$ PDs are prone to variability in emission rates, both between similarly made PDs and over time, and therefore require regular characterization but can provide a stable output over the order of weeks. While higher HONO outputs were possible to generate using an $\mathrm{NaNO}_{2}$-coated annular denuder for any given $\mathrm{HCl} \mathrm{PD}$, the outputs were unstable over time.

This HONO calibration instrument provides a universal solution to gas-phase HONO calibrations suitable for the full range of atmospheric instrumentation used for outdoor or indoor field measurements or laboratory experiments. This calibration unit could be used to intercompare the responses/measurements between HONO instruments to investigate and validate accuracy and precision of their ambient measurements in addition to identifying and isolating potential interferences (Crilley et al., 2019). We anticipate it will also find utility in the generation of isotopically labeled HONO for the emerging exploration of stable-isotopic composition of HONO and its relation to the wide variety of suspected atmospheric HONO sources (Chai et al., 2019).

Data availability. Datasets are presented in figures and summarized in tables throughout the paper and the Supplement. Raw data from these resources are available from the corresponding author upon request.

Supplement. The supplement related to this article is available online at: https://doi.org/10.5194/amt-13-5873-2020-supplement.

Author contributions. TCV, CJY, and RAW conceptualized the calibration source. TCV and CJY supervised the experiments, acquired the funding, and provided the resources to support this work. TCV designed the experiments, guided the investigations, and managed the project. ML constructed the custom PDs under the guidance of TCF and LS. ML and LS built the custom permeation oven and analyzed IC-CD samples. LRC and ML performed the mass balance, reaction device, and purity experiments. LRC and ML established and validated the methodologies. IB, JAN, AWR, PRV, RAW, and $\mathrm{CCW}$ provided instrumental resources and performed measurements included in the stability and purity experiments. LS created the schematics and wrote the detailed description of the custom permeation oven. ML constructed the reaction devices, performed part - or the entirety - of the experiments, and prepared the manuscript with contributions from all authors. All authors participated in data analysis, as well as the review and editing of the manuscript.

Competing interests. The authors declare that they have no conflict of interest.
Acknowledgements. The authors thank Elizabeth Gaona-Colmán for help in collecting the CIMS data, as well as John Liggio and Jeremy Wentzell for enabling the use of and training on the quadrupole CIMS. Melodie Lao acknowledges research support from an NSERC Undergraduate Student Research Award and travel support through a York University Fieldwork Cost Fund award. Leyla Salehpoor acknowledges research support from the Harold I. Schiff graduate award in Atmospheric Chemistry. Leigh R. Crilley and Trevor C. VandenBoer acknowledge travel support from the York University Faculty of Science Junior Faculty Fund. Cora J. Young acknowledges support for this project through an NSERC Discovery Grant. Trevor C. VandenBoer and Cora J. Young acknowledge funding for the instrumentation developed and used in this work provided by the Alfred P. Sloan Foundation Chemistry of Indoor Environments program.

Financial support. This research has been supported by the Alfred P. Sloan Foundation (grant no. G-2018-11051) and the Natural Sciences and Engineering Research Council of Canada (grant no. RGPIN-2018-05990).

Review statement. This paper was edited by Dwayne Heard and reviewed by three anonymous referees.

\section{References}

Braman, R. S. and de la Cantera, M. A.: Sublimation sources for nitrous acid and other nitrogen compounds in air, Anal. Chem., 58, 1533-1537, https://doi.org/10.1021/ac00298a059, 1986.

Chai, J., Miller, D. J., Scheuer, E., Dibb, J., Selimovic, V., Yokelson, R., Zarzana, K. J., Brown, S. S., Koss, A. R., Warneke, C., and Hastings, M.: Isotopic characterization of nitrogen oxides $\left(\mathrm{NO}_{x}\right)$, nitrous acid (HONO), and nitrate $\left(\mathrm{NOO}_{3}^{-}\right)$from laboratory biomass burning during FIREX, Atmos. Meas. Tech., 12, 6303-6317, https://doi.org/10.5194/amt-12-6303-2019, 2019.

Cheng, P., Cheng, Y., Lu, K., Su, H., Yang, Q., Zou, Y., Zhao, Y., Dong, H., Zeng, L., and Zhang, Y.: An online monitoring system for atmospheric nitrous acid (HONO) based on stripping coil and ion chromatography, J. Environ. Sci. (China), 25, 895-907, https://doi.org/10.1016/S1001-0742(12)60251-4, 2013.

Collins, D. B., Hems, R. F., Zhou, S., Wang, C., Grignon, E., Alavy, M., Siegel, J. A., and Abbatt, J. P. D.: Evidence for gas-surface equilibrium control of indoor nitrous acid, Environ. Sci. Technol., 52, 12419-12427, https://doi.org/10.1021/acs.est.8b04512, 2018.

Crilley, L. R., Kramer, L., Pope, F. D., Whalley, L. K., Cryer, D. R., Heard, D. E., Lee, J. D., Reed, C., and Bloss, W. J.: On the interpretation of in situ HONO observations via photochemical steady state, Faraday Discuss., 189, 191-212, https://doi.org/10.1039/c5fd00224a, 2016.

Crilley, L. R., Kramer, L. J., Ouyang, B., Duan, J., Zhang, W., Tong, S., Ge, M., Tang, K., Qin, M., Xie, P., Shaw, M. D., Lewis, A. C., Mehra, A., Bannan, T. J., Worrall, S. D., Priestley, M., Bacak, A., Coe, H., Allan, J., Percival, C. J., Popoola, O. A. M., Jones, R. L., and Bloss, W. J.: Intercomparison of nitrous acid (HONO) measurement techniques in a megacity (Beijing), At- 
mos. Meas. Tech., 12, 6449-6463, https://doi.org/10.5194/amt12-6449-2019, 2019.

Dawe, K. E. R., Furlani, T. C., Kowal, S. F., Kahan, T. F., VandenBoer, T. C., and Young, C. J.: Formation and emission of hydrogen chloride in indoor air, Indoor Air, 29, 70-78, https://doi.org/10.1111/ina.12509, 2019.

Elshorbany, Y. F., Kurtenbach, R., Wiesen, P., Lissi, E., Rubio, M., Villena, G., Gramsch, E., Rickard, A. R., Pilling, M. J., and Kleffmann, J.: Oxidation capacity of the city air of Santiago, Chile, Atmos. Chem. Phys., 9, 2257-2273, https://doi.org/10.5194/acp9-2257-2009, 2009.

Fahey, D. W., Eubank, C. S., Hübler, G., and Fehsenfeld, F. C.: Evaluation of a catalytic reduction technique for the measurement of total reactive odd-nitrogen $\mathrm{NO}_{y}$ in the atmosphere, J. Atmos. Chem., 3, 435-468, https://doi.org/10.1007/BF00053871, 1985.

Febo, A., Perrino, C., Gherardi, M., and Sparapani, R.: Evaluation of a high-purity and high-stability continuous generation system for nitrous acid, Environ. Sci. Technol., 29, 2390-2395, https://doi.org/10.1021/es00009a035, 1995.

Febo, A., Perrino, C., and Allegrini, I.: Measurement of nitrous acid in Milan, Italy, by DOAS and diffusion denuders, Atmos. Environ., 30, 3599-3609, https://doi.org/10.1016/13522310(96)00069-6, 1996.

Fontijn, A., Sabadell, A. J., and Ronco, R. J.: Homogeneous chemiluminescent measurement of nitric oxide with ozone: Implications for continuous selective monitoring of gaseous air pollutants, Anal. Chem., 42, 575-579, https://doi.org/10.1021/ac60288a034, 1970.

Fried, A., Henry, B., and Sewell, S.: Potential calibration errors in carbonyl sulfide permeation devices: Implications for atmospheric studies, J. Geophys. Res.-Atmos., 103, 18895-18906, https://doi.org/10.1029/98JD00620, 1998.

Gall, E. T., Griffin, R. J., Steiner, A. L., Dibb, J., Scheuer, E., Gong, L., Rutter, A. P., Cevik, B. K., Kim, S., Lefer, B., and Flynn, J.: Evaluation of nitrous acid sources and sinks in urban outflow, Atmos. Environ., 127, 272-282, https://doi.org/10.1016/j.atmosenv.2015.12.044, 2016.

Gingerysty, N. J. and Osthoff, H. D.: A compact, high-purity source of HONO validated by Fourier transform infrared and thermal-dissociation cavity ring-down spectroscopy, Atmos. Meas. Tech., 13, 4159-4167, https://doi.org/10.5194/amt-134159-2020, 2020.

Gligorovski, S.: Nitrous acid (HONO): An emerging indoor pollutant, J. Photochem. Photobiol. A Chem., 314, 1-5, https://doi.org/10.1016/j.jphotochem.2015.06.008, 2016.

Gómez Alvarez, E., Wortham, H., Strekowski, R., Zetzsch, C., and Gligorovski, S.: Atmospheric photosensitized heterogeneous and multiphase reactions: From outdoors to indoors, Environ. Sci. Technol., 46, 1955-1963, https://doi.org/10.1021/es2019675, 2012.

Harris, G. W., Carter, W. P. L., Winer, A. M., Pitts, J. N., Platt, U., and Perner, D.: Observations of Nitrous Acid in the Los Angeles Atmosphere and Implications for Predictions of OzonePrecursor Relationships, Environ. Sci. Technol., 16, 414-419, https://doi.org/10.1021/es00101a009, 1982.

Heland, J., Kleffmann, J., Kurtenbach, R., and Wiesen, P.: A new instrument to measure gaseous nitrous acid (HONO) in the atmosphere, Environ. Sci. Technol., 35, 3207-3212, https://doi.org/10.1021/es000303t, 2001.
Honrath, R. E., Lu, Y., Peterson, M. C., Dibb, J. E., Arsenault, M. A., Cullen, N. J., and Steffen, K.: Vertical fluxes of $\mathrm{NO}_{x}$, $\mathrm{HONO}$, and $\mathrm{HNO}_{3}$ above the snowpack at Summit, Greenland, Atmos. Environ., 36, 2629-2640, https://doi.org/10.1016/S13522310(02)00132-2, 2002.

Kasibhatla, P., Sherwen, T., Evans, M. J., Carpenter, L. J., Reed, C., Alexander, B., Chen, Q., Sulprizio, M. P., Lee, J. D., Read, K. A., Bloss, W., Crilley, L. R., Keene, W. C., Pszenny, A. A. P., and Hodzic, A.: Global impact of nitrate photolysis in sea-salt aerosol on $\mathrm{NO}_{x}, \mathrm{OH}$, and $\mathrm{O}_{3}$ in the marine boundary layer, Atmos. Chem. Phys., 18, 11185-11203, https://doi.org/10.5194/acp-1811185-2018, 2018.

Kim, S., VandenBoer, T. C., Young, C. J., Riedel, T. P., Thornton, J. A., Swarthout, B., Sive, B., Lerner, B., Gilman, J. B., Warneke, C., Roberts, J. M., Guenther, A., Wagner, N. L., Dubé, W. P., Williams, E., and Brown, S. S.: The primary and recyling source of $\mathrm{OH}$ during the NACHTT-2011 campaign: $\mathrm{HONO}$ as an important $\mathrm{OH}$ primary source in the wintertime, J. Geophys. Res.-Atmos., 119, 6886-6896, https://doi.org/10.1002/2013JD021186, 2014.

Kleffmann, J.: Daytime sources of nitrous acid (HONO) in the atmospheric boundary layer, ChemPhysChem, 8, 1137-1144, https://doi.org/10.1002/cphc.200700016, 2007.

Kleffmann, J. and Wiesen, P.: Technical Note: Quantification of interferences of wet chemical HONO LOPAP measurements under simulated polar conditions, Atmos. Chem. Phys., 8, 6813-6822, https://doi.org/10.5194/acp-8-6813-2008, 2008.

Kleffmann, J., Benter, T., and Wiesen, P.: Heterogeneous reaction of nitric acid with nitric oxide on glass surfaces under simulated atmospheric conditions, J. Phys. Chem. A, 108, 5793-5799, https://doi.org/10.1021/jp040184u, 2004.

Kleffmann, J., Lörzer, J. C., Wiesen, P., Kern, C., Trick, S., Volkamer, R., Rodenas, M., and Wirtz, K.: Intercomparison of the DOAS and LOPAP techniques for the detection of nitrous acid (HONO), Atmos. Environ., 40, 3640-3652, https://doi.org/10.1016/j.atmosenv.2006.03.027, 2006.

Lee, B. H., Wood, E. C., Herndon, S. C., Lefer, B. L., Luke, W. T., Brune, W. H., Nelson, D. D., Zahniser, M. S., and Munger, J. W.: Urban measurements of atmospheric nitrous acid: A caveat on the interpretation of the HONO photostationary state, J. Geophys. Res.-Atmos., 118, 12274-12281, https://doi.org/10.1002/2013JD020341, 2013.

Lee, J. D., Whalley, L. K., Heard, D. E., Stone, D., Dunmore, R. E., Hamilton, J. F., Young, D. E., Allan, J. D., Laufs, S., and K1effmann, J.: Detailed budget analysis of HONO in central London reveals a missing daytime source, Atmos. Chem. Phys., 16, 2747-2764, https://doi.org/10.5194/acp-16-2747-2016, 2016.

Liu, J., Li, S., Zeng, J., Mekic, M., Yu, Z., Zhou, W., Loisel, G., Gandolfo, A., Song, W., Wang, X., Zhou, Z., Herrmann, H., Li, X., and Gligorovski, S.: Assessing indoor gas phase oxidation capacity through real-time measurements of $\mathrm{HONO}$ and $\mathrm{NO}_{x}$ in Guangzhou, China, Environ. Sci. Process. Impacts, 21, 13931402, https://doi.org/10.1039/c9em00194h, 2019.

MacInnis, J. J., VandenBoer, T. C., and Young, C. J.: Development of a gas phase source for perfluoroalkyl acids to examine atmospheric sampling methods, Analyst, 141, 3765-3775, https://doi.org/10.1039/c6an00313c, 2016.

McGrath, D. T., Ryan, M. D., Macinnis, J. J., Vandenboer, T. C., Young, C. J., and Katz, M. J.: Selective decontamination of the 
reactive air pollutant nitrous acid via node-linker cooperativity in a metal-organic framework, Chem. Sci., 10, 5576-5581, https://doi.org/10.1039/c9sc01357a, 2019.

Min, K.-E., Washenfelder, R. A., Dubé, W. P., Langford, A. O., Edwards, P. M., Zarzana, K. J., Stutz, J., Lu, K., Rohrer, F., Zhang, Y., and Brown, S. S.: A broadband cavity enhanced absorption spectrometer for aircraft measurements of glyoxal, methylglyoxal, nitrous acid, nitrogen dioxide, and water vapor, Atmos. Meas. Tech., 9, 423-440, https://doi.org/10.5194/amt-9423-2016, 2016.

Mitchell, G. D.: A review of permeation tubes and permeators, Sep. Purif. Methods, 29, 119-128, https://doi.org/10.1081/SPM100100005, 2000.

Mushinski, R. M., Phillips, R. P., Payne, Z. C., Abney, R. B., Jo, I., Fei, S., Pusede, S. E., White, J. R., Rusch, D. B., and Raff, J. D.: Microbial mechanisms and ecosystem flux estimation for aerobic $\mathrm{NO}_{y}$ emissions from deciduous forest soils, P. Natl. Acad. Sci. USA, 116, 2138-2145, https://doi.org/10.1073/pnas.1814632116, 2019.

Neuman, J. A., Ryerson, T. B., Huey, L. G., Jakoubek, R., Nowak, J. B., Simons, C., and Fehsenfeld, F. C.: Calibration and evaluation of nitric acid and ammonia permeation tubes by UV optical absorption, Environ. Sci. Technol., 37, 2975-2981, https://doi.org/10.1021/es0264221, 2003.

Neuman, J. A., Trainer, M., Brown, S. S., Min, K. E., Nowak, J. B., Parrish, D. D., Peischl, J., Pollack, I. B., Roberts, J. M., Ryerson, T. B., and Veres, P. R.: HONO emission and production determined from airborne measurements over the Southeast U.S., J. Geophys. Res.-Atmos., 121, 9237-9250, https://doi.org/10.1002/2016JD025197, 2016.

O'Keeffe, A. E. and Ortman, G. C.: Primary standards for trace gas analysis, Anal. Chem., 38, 760-763, https://doi.org/10.1021/ac60238a022, 1966.

Oswald, R., Behrendt, T., Ermel, M., Wu, D., Su, H., Cheng, Y., Breuninger, C., Moravek, A., Mougin, E., Delon, C., Loubet, B., Pommerening-Röser, A., Sörgel, M., Pöschl, U., Hoffmann, T., Andreae, M. O., Meixner, F. X., and Trebs, I.: HONO emissions from soil bacteria as a major source of atmospheric reactive nitrogen, Science, 341, 1233-1235, https://doi.org/10.1126/science.1242266, 2013.

Pinto, J. P., Dibb, J., Lee, B. H., Rappenglück, B., Wood, E. C., Levy, M., Zhang, R. Y., Lefer, B., Ren, X. R., Stutz, J., Tsai, C., Ackermann, L., Golovko, J., Herndon, S. C., Oakes, M., Meng, Q. Y., Munger, J. W., Zahniser, M., and Zheng, J.: Intercomparison of field measurements of nitrous acid (HONO) during the SHARP campaign, J. Geophys. Res.-Atmos., 119, 5583-5601, https://doi.org/10.1002/2013JD020287, 2014.

Place, B. K., Young, C. J., Ziegler, S. E., Edwards, K. A., Salehpoor, L., and VandenBoer, T. C.: Passive sampling capabilities for ultra-trace quantitation of atmospheric nitric acid $\left(\mathrm{HNO}_{3}\right)$ in remote environments, Atmos. Environ., 191, 360369, https://doi.org/10.1016/j.atmosenv.2018.08.030, 2018.

Pusede, S. E., VandenBoer, T. C., Murphy, J. G., Markovic, M. Z., Young, C. J., Veres, P. R., Roberts, J. M., Washenfelder, R. A., Brown, S. S., Ren, X., Tsai, C., Stutz, J., Brune, W. H., Browne, E. C., Wooldridge, P. J., Graham, A. R., Weber, R., Goldstein, A. H., Dusanter, S., Griffith, S. M., Stevens, P. S., Lefer, B. L., and Cohen, R. C.: An atmospheric constraint on the $\mathrm{NO}_{2}$ dependence of daytime near-surface ni- trous acid (HONO), Environ. Sci. Technol., 49, 12774-12781, https://doi.org/10.1021/acs.est.5b02511, 2015.

Reed, C., Evans, M. J., Crilley, L. R., Bloss, W. J., Sherwen, T., Read, K. A., Lee, J. D., and Carpenter, L. J.: Evidence for renoxification in the tropical marine boundary layer, Atmos. Chem. Phys., 17, 4081-4092, https://doi.org/10.5194/acp17-4081-2017, 2017.

Ren, X., Gao, H., Zhou, X., Crounse, J. D., Wennberg, P. O., Browne, E. C., LaFranchi, B. W., Cohen, R. C., McKay, M., Goldstein, A. H., and Mao, J.: Measurement of atmospheric nitrous acid at Bodgett Forest during BEARPEX2007, Atmos. Chem. Phys., 10, 6283-6294, https://doi.org/10.5194/acp-106283-2010, 2010.

Ridley, B. A. and Grahek, F. E.: A small, low flow, high sensitivity reaction vessel for NO chemiluminescence detectors, J. Am. Meteorol. Soc., 7, 307-311, 1990.

Ridley, B. A. and Howlett, L. C.: An instrument for nitric oxide measurements in the stratosphere, Rev. Sci. Instrum., 45, 742746, 1974.

Roberts, J. M., Veres, P., Warneke, C., Neuman, J. A., Washenfelder, R. A., Brown, S. S., Baasandorj, M., Burkholder, J. B., Burling, I. R., Johnson, T. J., Yokelson, R. J., and de Gouw, J.: Measurement of HONO, HNCO, and other inorganic acids by negative-ion proton-transfer chemical-ionization mass spectrometry (NI-PT-CIMS): application to biomass burning emissions, Atmos. Meas. Tech., 3, 981-990, https://doi.org/10.5194/amt-3981-2010, 2010.

Rollins, A. W., Rickly, P. S., Gao, R.-S., Ryerson, T. B., Brown, S. S., Peischl, J., and Bourgeois, I.: Single-photon laserinduced fluorescence detection of nitric oxide at sub-parts-pertrillion mixing ratios, Atmos. Meas. Tech., 13, 2425-2439, https://doi.org/10.5194/amt-13-2425-2020, 2020.

Rubio, M. A., Lissi, E., Villena, G., Elshorbany, Y. F., Kleffmann, J., Kurtenbach, R., and Wiesen, P.: Simultaneous measurements of formaldehyde and nitrous acid in dews and gas phase in the atmosphere of Santiago, Chile, Atmos. Environ., 43, 6106-6109, https://doi.org/10.1016/j.atmosenv.2009.09.017, 2009.

Ryerson, T. B., Huey, L. G., Knapp, K., Neuman, J. A., Parrish, D. D., Sueper, D. T., and Fehsenfeld, F. C.: Design and initial characterization of an inlet for gas-phase $\mathrm{NO}_{y}$ measurements from aircraft, J. Geophys. Res., 104, 5483-5492, 1999.

Sörgel, M., Trebs, I., Serafimovich, A., Moravek, A., Held, A., and Zetzsch, C.: Simultaneous HONO measurements in and above a forest canopy: influence of turbulent exchange on mixing ratio differences, Atmos. Chem. Phys., 11, 841-855, https://doi.org/10.5194/acp-11-841-2011, 2011.

Sörgel, M., Trebs, I., Wu, D., and Held, A.: A comparison of measured HONO uptake and release with calculated source strengths in a heterogeneous forest environment, Atmos. Chem. Phys., 15, 9237-9251, https://doi.org/10.5194/acp-15-9237-2015, 2015.

Spataro, F. and Ianniello, A.: Sources of atmospheric nitrous acid: State of the science, current research needs, and future prospects, J. Air Waste Manag. Assoc., 64, 1232-1250, https://doi.org/10.1080/10962247.2014.952846, 2014.

Stutz, J., Kim, E. S., Platt, U., Bruno, P., Perrino, C., and Febo, A.: UV-visible absorption cross sections of nitrous acid, J. Geophys. Res.-Atmos., 105, 14585-14592, https://doi.org/10.1029/2000JD900003, 2000. 
Stutz, J., Oh, H. J., Whitlow, S. I., Anderson, C., Dibb, J. E., Flynn, J. H., Rappenglück, B., and Lefer, B.: Simultaneous DOAS and mist-chamber IC measurements of HONO in Houston, TX, Atmos. Environ., 44, 4090-4098, https://doi.org/10.1016/j.atmosenv.2009.02.003, 2010.

Susaya, J., Kim, K. H., Cho, J., and Parker, D.: The controlling effect of temperature in the application of permeation tube devices in standard gas generation, J. Chromatogr. A, 1225, 8-16, https://doi.org/10.1016/j.chroma.2011.12.066, 2012.

Taira, M. and Kanda, Y.: Continuous generation system for lowconcentration gaseous nitrous acid, Anal. Chem., 62, 630-633, https://doi.org/10.1021/ac00205a018, 1990.

Tong, S., Hou, S., Zhang, Y., Chu, B., Liu, Y., He, H., Zhao, P., and Ge, M.: Exploring the nitrous acid (HONO) formation mechanism in winter Beijing: Direct emissions and heterogeneous production in urban and suburban areas, Faraday Discuss., 189, 213230, https://doi.org/10.1039/c5fd00163c, 2016.

Tsai, C., Spolaor, M., Colosimo, S. F., Pikelnaya, O., Cheung, R., Williams, E., Gilman, J. B., Lerner, B. M., Zamora, R. J., Warneke, C., Roberts, J. M., Ahmadov, R., de Gouw, J., Bates, T., Quinn, P. K., and Stutz, J.: Nitrous acid formation in a snow-free wintertime polluted rural area, Atmos. Chem. Phys., 18, 19771996, https://doi.org/10.5194/acp-18-1977-2018, 2018.

VandenBoer, T. C., Brown, S. S., Murphy, J. G., Keene, W. C., Young, C. J., Pszenny, A. A. P., Kim, S., Warneke, C., De Gouw, J. A., Maben, J. R., Wagner, N. L., Riedel, T. P., Thornton, J. A., Wolfe, D. E., Dubé, W. P., Öztürk, F., Brock, C. A., Grossberg, N., Lefer, B., Lerner, B., Middlebrook, A. M., and Roberts, J. M.: Understanding the role of the ground surface in HONO vertical structure: High resolution vertical profiles during NACHTT-11, J. Geophys. Res.-Atmos., 118, 10155-10171, https://doi.org/10.1002/jgrd.50721, 2013.

VandenBoer, T. C., Markovic, M. Z., Sanders, J. E., Ren, X., Pusede, S. E., Browne, E. C., Cohen, R. C., Zhang, L., Thomas, J., Brune, W. H., and Murphy, J. G.: Evidence for a nitrous acid (HONO) reservoir at the ground surface in Bakersfield, CA, during CalNex 2010, J. Geophys. Res.-Atmos., 119, 9093-9106, https://doi.org/10.1002/2013JD020971, 2014.

VandenBoer, T. C., Young, C. J., Talukdar, R. K., Markovic, M. Z., Brown, S. S., Roberts, J. M., and Murphy, J. G.: Nocturnal loss and daytime source of nitrous acid through reactive uptake and displacement, Nat. Geosci., 8, 55-60, https://doi.org/10.1038/ngeo2298, 2015.

Večeřa, Z. and Dasgupta, P. K.: Measurement of ambient nitrous acid and a reliable calibration source for gaseous nitrous acid, Environ. Sci. Technol., 25, 255-260, https://doi.org/10.1021/es00014a006, 1991.

Veres, P., Gilman, J. B., Roberts, J. M., Kuster, W. C., Warneke, C., Burling, I. R., and de Gouw, J.: Development and validation of a portable gas phase standard generation and calibration system for volatile organic compounds, Atmos. Meas. Tech., 3, 683-691, https://doi.org/10.5194/amt-3-683-2010, 2010a.

Veres, P., Roberts, J. M., Burling, I. R., Warneke, C., De Gouw, J., and Yokelson, R. J.: Measurements of gas-phase inorganic and organic acids from biomass fires by negative-ion proton-transfer chemical-ionization mass spectrometry, J. Geophys. Res.Atmos., 115, D23302, https://doi.org/10.1029/2010JD014033, 2010b.
Veres, P. R., Andrew Neuman, J., Bertram, T. H., Assaf, E., Wolfe, G. M., Williamson, C. J., Weinzierl, B., Tilmes, S., Thompson, C. R., Thames, A. B., Schroder, J. C., Saiz-Lopez, A., Rollins, A. W., Roberts, J. M., Price, D., Peischl, J., Nault, B. A., Møller, K. H., Miller, D. O., Meinardi, S., Li, Q., Lamarque, J. F., Kupc, A., Kjaergaard, H. G., Kinnison, D., Jimenez, J. L., Jernigan, C. M., Hornbrook, R. S., Hills, A., Dollner, M., Day, D. A., Cuevas, C. A., Campuzano-Jost, P., Burkholder, J., Bui, T. P., Brune, W. H., Brown, S. S., Brock, C. A., Bourgeois, I., Blake, D. R., Apel, E. C., and Ryerson, T. B.: Global airborne sampling reveals a previously unobserved dimethyl sulfide oxidation mechanism in the marine atmosphere, P. Natl. Acad. Sci. USA, 117, 4505-4510, https://doi.org/10.1073/pnas.1919344117, 2020.

Volkamer, R., Sheehy, P., Molina, L. T., and Molina, M. J.: Oxidative capacity of the Mexico City atmosphere - Part 1: A radical source perspective, Atmos. Chem. Phys., 10, 6969-6991, https://doi.org/10.5194/acp-10-6969-2010, 2010.

Wang, L. and Zhang, J.: Detection of nitrous acid by cavity ring-down spectroscopy, Environ. Sci. Technol., 34, 4221-4227, https://doi.org/10.1021/es0011055, 2000.

Washenfelder, R. A., Roehl, C. M., McKinney, K. A., Julian, R. R., and Wennberg, P. O.: A compact, lightweight gas standards generator for permeation tubes, Rev. Sci. Instrum., 74, 3151-3154, https://doi.org/10.1063/1.1570949, 2003.

Ye, C., Zhou, X., Pu, D., Stutz, J., Festa, J., Spolaor, M., Tsai, C., Cantrell, C., Mauldin, R. L., Campos, T., Weinheimer, A., Hornbrook, R. S., Apel, E. C., Guenther, A., Kaser, L., Yuan, B., Karl, T., Haggerty, J., Hall, S., Ullmann, K., Smith, J. N., Ortega, J., and Knote, C.: Rapid cycling of reactive nitrogen in the marine boundary layer, Nature, 532, 489-491, https://doi.org/10.1038/nature17195, 2016.

Ye, C., Zhou, X., Pu, D., Stutz, J., Festa, J., Spolaor, M., Tsai, C., Cantrell, C., Mauldin III, R. L., Weinheimer, A., Hornbrook, R. S., Apel, E. C., Guenther, A., Kaser, L., Yuan, B., Karl, T., Haggerty, J., Hall, S., Ullmann, K., Smith, J., and Ortega, J.: Tropospheric HONO distribution and chemistry in the southeastern US, Atmos. Chem. Phys., 18, 9107-9120, https://doi.org/10.5194/acp-18-9107-2018, 2018.

Young, C. J., Washenfelder, R. A., Roberts, J. M., Mielke, L. H., Osthoff, H. D., Tsai, C., Pikelnaya, O., Stutz, J., Veres, P. R., Cochran, A. K., Vandenboer, T. C., Flynn, J., Grossberg, N., Haman, C. L., Lefer, B., Stark, H., Graus, M., De Gouw, J., Gilman, J. B., Kuster, W. C., and Brown, S. S.: Vertically resolved measurements of nighttime radical reservoirs in Los Angeles and their contribution to the urban radical budget, Environ. Sci. Technol., 46, 10965-10973, https://doi.org/10.1021/es302206a, 2012.

Young, C. J., Zhou, S., Siegel, J. A., and Kahan, T. F.: Illuminating the dark side of indoor oxidants, Environ. Sci. Process. Impacts, 21, 1229-1239, https://doi.org/10.1039/c9em00111e, 2019.

Zhang, N., Zhou, X., Shepson, P. B., Gao, H., Alaghmand, M., and Stirm, B.: Aircraft measurement of HONO vertical profiles over a forested region, Geophys. Res. Lett., 36, L15820, https://doi.org/10.1029/2009GL038999, 2009.

Zhang, W., Tong, S., Ge, M., An, J., Shi, Z., Hou, S., Xia, K., Qu, Y., Zhang, H., Chu, B., Sun, Y., and He, H.: Variations and sources of nitrous acid (HONO) during a severe pollution episode in Beijing in winter 2016, Sci. Total Environ., 648, 253 262, https://doi.org/10.1016/j.scitotenv.2018.08.133, 2019. 
Zhou, S., Young, C. J., Vandenboer, T. C., Kowal, S. F., and Kahan, T. F.: Time-resolved measurements of nitric oxide, nitrogen dioxide, and nitrous acid in an occupied New York home, Environ. Sci. Technol., 52, 8355-8364, https://doi.org/10.1021/acs.est.8b01792, 2018.
Zhou, X., He, Y., Huang, G., Thornberry, T. D., Carroll, M. A., and Bertman, S. B.: Photochemical production of nitrous acid on glass sample manifold surface, Geophys. Res. Lett., 29, 1681, https://doi.org/10.1029/2002g1015080, 2002. 